\title{
Los artistas como criticos. Reseñas sobre pintura hechas por artistas plásticos en el Boletín Mensual Carta Blanca, 1934-1939
}

\section{The Artists as Critics. Art Reviews Written by Painters in the Boletín Mensual Carta Blanca, 1934-1939}

Artículo recibido el 2 de febrero de 20I6, devuelto para revisión el i8 de marzo de 20I6; aceptado el I9 de octubre de 20I6. http://dx.doi.org/Io.2220I/iie.I8703062e.20I7.I.2594

Roberto Aceves Ávila El Colegio de Jalisco, México. racevesa@hotmail.com

Líneas de investigación Historia de las devociones religiosas; el arte y la cultura de Jalisco.

Lines or research History of religious cults; art and culture of Jalisco.

Publicaciones más relevantes "El culto a la Virgen de Zapopan durante el periodo colonial", Intersticios Sociales, año 6, núm. II (20I6): I-44; "El culto a San Gonzalo de Amarante, El Bailador", Relaciones. Estudios de historia y sociedad XXXVII, núm. I45 (2016): IO9-I50; "Sobre el 'Manifiesto Justificativo de los Castigos Nacionales en Querétaro' atribuido a Benito Juárez", en Compendio de las XIII Jornadas Académicas (Universidad Nacional Autónoma de México-Instituto de Investigaciones Bibliográficas, 20I4): 59-75.

Resumen Se rescatan ocho artículos de crítica de obras de arte publicados por David Alfaro Siqueiros (sobre Echave el Mozo y Carlos Orozco Romero), Carlos Orozco Romero (sobre Alvise Vivarini), Carlos Mérida (Peeter Jansz Pourbus, el Viejo, Francisco Goitia, Antonio Ruiz y Eugenio Landesio) y Roberto Montenegro (Ovens Juriane). Se publicaron originalmente en el Boletín Mensual Carta Blanca, entre 1935 y I938 y no se habían reimpreso. Los artículos van precedidos de una breve historia del Boletín, creado por Salvador Novo a instancias de Xavier Villaurrutia, una descripción de sus contenidos, el contexto y las condiciones de su creación. Se señala la contribución del Boletín para divulgar la opinión y la crítica sobre artes visuales y para promover la obra de artistas tanto antiguos como contemporáneos mediante un folleto publicitario de calidad, que contribuyó a la difusión de la cultura en México durante la década de los años treinta del siglo xx.

Palabras clave Boletín Mensual Carta Blanca; Contemporáneos; crítica de arte en México; Carlos Orozco Romero; Carlos Mérida. 
Abstract This study brings together eight art reviews by Latin-American artists: David Alfaro Siqueiros (on painters Echave el Mozo and Carlos Orozco Romero), Carlos Orozco Romero (on Alvise Vivarini), Carlos Mérida (on Pieter Jansz Pourbus the Elder, Francisco Goitia, Antonio Ruiz and Eugenio Landesio), and Roberto Montenegro (on Ovens Juriane). The articles were originally published in the Boletin Mensual Carta Blanca, between 1935 and 1938 , and have not been republished since. Their presentation is preceded by a short account of the Boletin, created by Salvador Novo at the insistence of Xavier Villaurrutia, as well as by a description of its contents, context and the conditions under which it came into being. We highlight the role of the Boletín in disseminating opinions and critical reviews on visual arts, and promoting the work of contemporary as well as classic artists, in the form of a high quality advertising pamphlet that contributed to the dissemination of culture in Mexico during the I930s.

Keywords Boletín Mensual Carta Blanca; Contemporáneos; Art reviews in Mexico; Carlos Orozco Romero; Carlos Mérida. 
DOI: http://dx.doi.org/10.22201/iie.18703062e.2017.1.2594

\author{
ROBERTO ACEVES ÁVILA \\ EL COLEGIO DE JALISCO \\ MÉXICO
}

\title{
Los artistas como críticos. Reseñas sobre pintura bechas por artistas plásticos en el Boletín Mensual Carta Blanca, I934-1939
}

$\mathrm{E}$ ntre junio de 1934 y enero de 1939 la cervecería Cuauhtémoc de México, con el apoyo de varios escritores y artistas plásticos que pertenecieron en su mayoría a los grupos literarios Ulises, Contemporáneos y Examen, llevó a cabo una interesante obra de difusión cultural que hoy resulta de difícil acceso, y en algunos casos, es prácticamente desconocida. Se trata del Boletín Mensual Carta Blanca, una publicación periódica privada hecha con fines publicitarios de la que se editaron alrededor de 53 números y que ejemplifica el interés de las vanguardias de la primera mitad del siglo xx por participar en medios populares masivos de difusión.

El Boletín tenía como finalidad primordial promocionar el consumo de la cerveza Carta Blanca entre la población de mayores ingresos, como lo muestran los anuncios que ilustraban el interior y la contraportada, que procuraban vincular en su publicidad y en sus artículos el consumo de dicha cerveza con la gastronomía, las actividades culturales y deportivas, la celebración de fiestas y con el mundo del arte. Dada la naturaleza publicitaria de dicho boletín, y su consiguiente apreciación como literatura de difusión, prácticamente no existen colecciones completas del mismo. ${ }^{\mathrm{I}}$

I. La colección más completa de la revista se localiza en la Biblioteca de la Universidad Iberoamericana Francisco Xavier Clavigero, en la Colección Gonzalo Obregón. Sólo que los ejemplares se encuentran clasificados no de manera conjunta, sino de acuerdo con el nombre específico que tenía la publicación en cada una de sus etapas. Así, el catálogo electrónico de la institución señala 
En general se puede afirmar que hasta ahora, el Boletin Mensual Carta Blan$c a$ no se ha estudiado en forma integral. Ciertamente su importancia la han señalado autores como Miguel Capistrán y Luis Mario Schneider, y de sus páginas se han rescatado las colaboraciones de Xavier Villaurrutia, Salvador Novo, Jorge Cuesta, Carlos Pellicer e incluso Antonin Artaud, para integrarlas a sus obras completas. Sin embargo, todavía está pendiente recuperar las colaboraciones de Bernardo Ortiz de Montellano, Octavo G. Barreda, o del escritor y diplomático de Zapotlán, Guillermo Jiménez, por ejemplo. Tampoco se han abordado los testimonios de los artistas plásticos que colaboraron como críticos en sus páginas, y que contribuyeron a las reflexiones y al ambiente literario y estético de la época. Por ello, a manera de rescate, y con la idea de contribuir a un análisis más integral de los contenidos del Boletín Mensual Carta Blanca, presento ocho notas de artistas plásticos (David Alfaro Siqueiros, Carlos Mérida, Carlos Orozco Romero y Roberto Montenegro) que participaron como críticos de obras de arte en dicha publicación entre 1935 y 1938. Por otra parte, difundir algunos elementos del diseño, de los contenidos y la forma de promover la cultura a través de un medio publicitario, como la publicación reseñada en esta nota, puede ser de interés para futuros trabajos sobre fuentes para la historia del arte en México.

la existencia de los números del I al 8 de los io correspondientes a 1934 bajo el rubro de "Galería de Pintores Modernos Mexicanos", diez correspondientes a I935 bajo la denominación "El arte en México. Pintura colonial”, y los números que van del I, de I936, hasta el 6, de I938, bajo el rubro de "Boletín Mensual Carta Blanca" y "Boletín de Arte Carta Blanca". Ésta es la colección más completa detectada hasta ahora que puede consultarse en un repositorio público. Existen otras colecciones incompletas en diversas instituciones. Por ejemplo, el catálogo de la Hemeroteca Nacional de México en su colección de Revistas Mexicanas tiene clasificados únicamente los números correspondientes a marzo de 1937 (año 4, núm. I) hasta junio de 1938 (año 5, núm. 3) y faltan varios ejemplares. Existen en los Fondos Reservados de la Biblioteca Nacional (Colección Especial María Asúnsolo) I3 números empastados en un volumen correspondiente al año 4, números del I al I3 (marzo de 1937 a marzo de 1938). Por otra parte, los compiladores de las crónicas y artículos periodísticos de Novo señalan que dicho autor "conservó entre sus papeles un volumen empastado que contiene el Boletín Mensual Carta Blanca de marzo de 1936 a enero de 1939", pero se limitan a publicar el contenido cuya autoría es de Novo y no describen el resto de la publicación (véase Salvador Novo, Viajes y ensayos II. Crónicas y artículos periodísticos, comp. y ed. Sergio González Rodríguez y Lligany Lomelí [México: Fondo de Cultura Económica, 1999], 564 nota). El Centro de Estudios de Historia de México Carso posee I2 ejemplares del Boletín (Monserrat Ugalde Bravo, "Boletines de arte moderno de la Cervecería Cuauhtémoc", Revista Mensual Museo Soumaya Fundación Carlos Slim (septiembre, 20I5): 27-29; consultado el 28 de enero, 2016, http://www.museosoumaya.com. $\mathrm{mx} /$ index.php/esp/inicio/revistas\#. 
De acuerdo con la información disponible, a lo largo de su existencia, el Boletín publicó un total de 53 números, agrupados en cinco series temáticas de pintura: Galería de Pintores Modernos Mexicanos (io números, de marzo a diciembre de 1934); El Arte en México. Pintura Colonial (II números, de abril de 1935 a febrero de 1936); Pintura Europea de los Siglos XIV y XV en Colecciones de México (I2 números, de marzo de 1936 a febrero de 1937); El Arte en México. Pintura Moderna. Pintores Modernos Mexicanos (I 3 números, de marzo de 1937 a marzo de 1938); y La Pintura Mexicana de finales del Siglo XIX y principios del xx. Pintura de los Siglos XIX y Xx (7 números, de abril de 1938 a enero de 1939). Los tres números finales de la última serie fueron bimestrales, por lo que la revista cambió su nombre a Boletín de Arte Carta Blanca.

En el cuadro i que aparece como anexo al final de esta nota se presenta la relación de obras de arte reseñadas y sus respectivos comentaristas que se publicaron en el Boletín. Debe destacarse la gran variedad de puntos de vista incluidos en la publicación, pues de acuerdo con una hoja suelta inserta en el Boletín a partir del inicio de la serie de Pintores Modernos Mexicanos, éste no perseguía "otro fin sino hacer una divulgación cultural. Ajena por completo a todo sectarismo preferencias que desvirtuarían esta acción, en esta Galería tendrán cabida aquellos que hayan realizado una valiosa labor original, sea cual fuere la ideología que la hubiese inspirado". Este mismo comentario fue válido para los autores de las notas críticas, los cuales provenían de todos los ámbitos del espectro ideológico de México en aquel momento, desde Pedro Zuloaga, quien fuese miembro fundador del Partido Acción Nacional, hasta David Alfaro Siqueiros, militante declarado de izquierda.

El diseño editorial de la revista procuraba perfilar a los lectores, al esmerarse en la impresión y variedad de secciones al interior. Aunque los formatos variaron a lo largo de los años, por lo general, el Boletín era un folleto sin paginación de tamaño carta $(21.5 \times 28 \mathrm{~cm})$ que se componía de portada, seguido de una primera hoja que contenía una sección de notas culturales escrita por Novo (Estampas del México Viejo) o por algún otro autor anónimo o con seudónimo (como por ejemplo el periodista Guillermo Enríquez Simoní, bajo el seudónimo de Pepe Rouletabille); ${ }^{2}$ e invariablemente aparecía la nota referente a la imagen de la obra de arte seleccionada, la cual se reproducía a color al frente de la nota. Para proteger la impresión a color se incluía una hoja suelta

2. Sobre la identidad de este escritor, véase Héctor Perea, "Un testigo de levita", consultado el 28 de enero de 20I6, http://issuu.com/laberintomilenio/docs/laberinto-499. 
impresa en papel de china en la que se hacía la descripción de la serie a la que pertenecía la imagen a color incluida en el boletín.

La siguiente página se dedicaba a notas culturales referentes a la historia, fabricación y beneficios de la cerveza, recetas de cocina, imágenes y descripciones de costumbres relacionadas con la bebida y los brindis, e incluso estaban ilustradas con imágenes a color de platillos gastronómicos sofisticados preparados por diversos chefs de restaurantes de lujo o clubes sociales a solicitud del redactor de la revista (en este caso Novo). Invariablemente todas estas notas terminaban invitando a los lectores a consumir y brindar con la cerveza Carta Blanca. En la última página siempre se incluía un anuncio de la misma cerveza.

A lo largo de su historia, el Boletín sufrió múltiples cambios en el nombre, diseño y formato. Durante el primer año el Boletín se llamó Galería de Pintores Modernos Mexicanos, y sólo incluía en las páginas centrales la imagen reseñada y la nota crítica correspondiente. A partir de entonces, todas las reseñas sobre arte se acompañaron de la fotografía de su autor, junto con la reproducción de su firma hológrafa (véase figs. I y 2). Durante el segundo año, la publicación cambió su nombre al de Boletín Mensual Carta Blan$c a$, y el folleto que contenía la reseńa sobre arte y la reproducción de la obra reseñada se convirtió en un anexo que venía dentro de una sobrecubierta en la que se incluían los artículos y secciones ya mencionados, incluyendo además en la portada de dicha sobrecubierta una historia o leyenda sobre la historia de la cerveza o de otra bebida espirituosa, escritos por autor anónimo, y con una ilustración del artista publicitario Fernando Bolaños Cacho, quien también dibujó muchas de las imágenes publicitarias de Carta Blanca (véase figs. 3 y 4). La crítica de arte y la reproducción correspondiente se publicaron como un anexo llamado El Arte en México. Pintura Colonial, contenido al interior de la sobrecubierta (véase figs. 5 y 6 ).

A partir del tercer año, el Boletín cambió su formato a una especie de tríptico, al eliminar la sobrecubierta, e incorporar todas las secciones y notas al cuerpo del boletín, agregando una solapa que se doblaba en portada sobre el cuerpo de la revista. Al abrirse la publicación se observaba por lo general la fotografía y descripción de un elaborado platillo gastronómico preparado por un chef de un restaurante famoso de México, a invitación del editor (en este caso Novo, autor de varias de estas descripciones gastronómicas). En dicho texto invariablemente se recomendaba acompañar el platillo con cerveza Carta Blanca. Al desdoblar esta solapa, en la parte central del interior siempre aparecía la nota crítica de la obra de arte y la reproducción a color de la misma. El color de 
DOI: http://dx.doi.org/10.22201/iie.18703062e.2017.1.2594

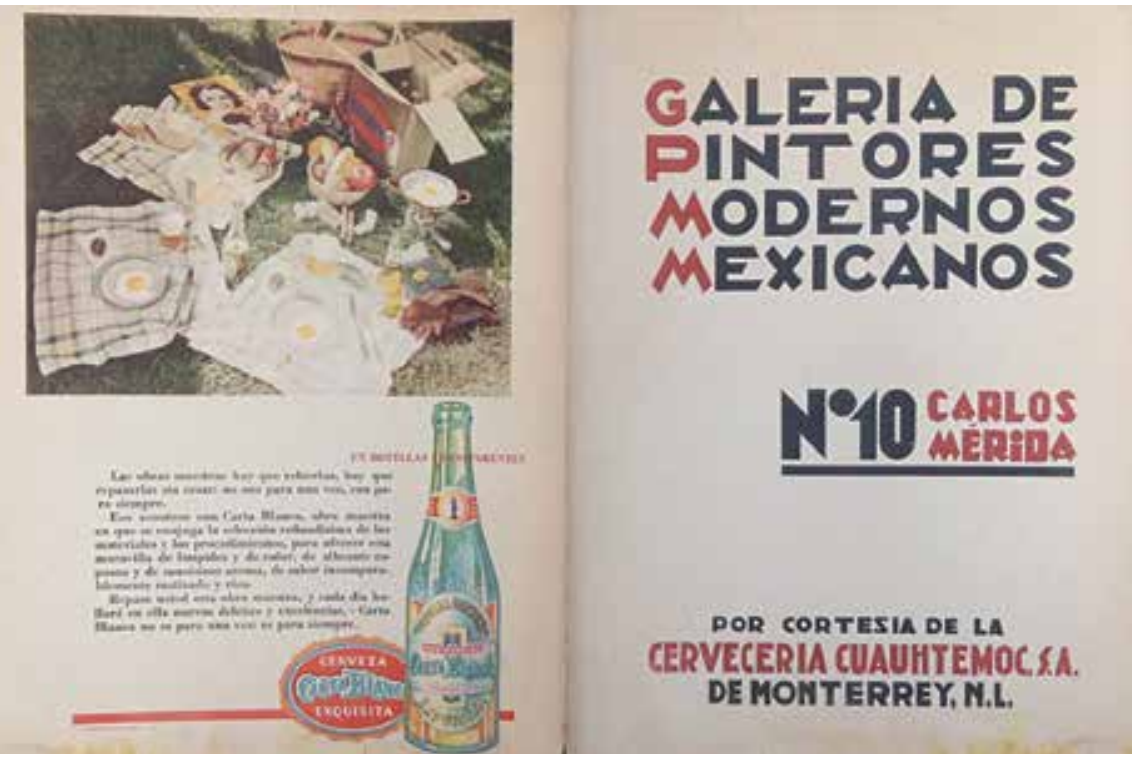

I. Contraportada y portada de Galería de Pintores Modernos Mexicanos, ca. 1934. Colección particular. Fotografía del autor.

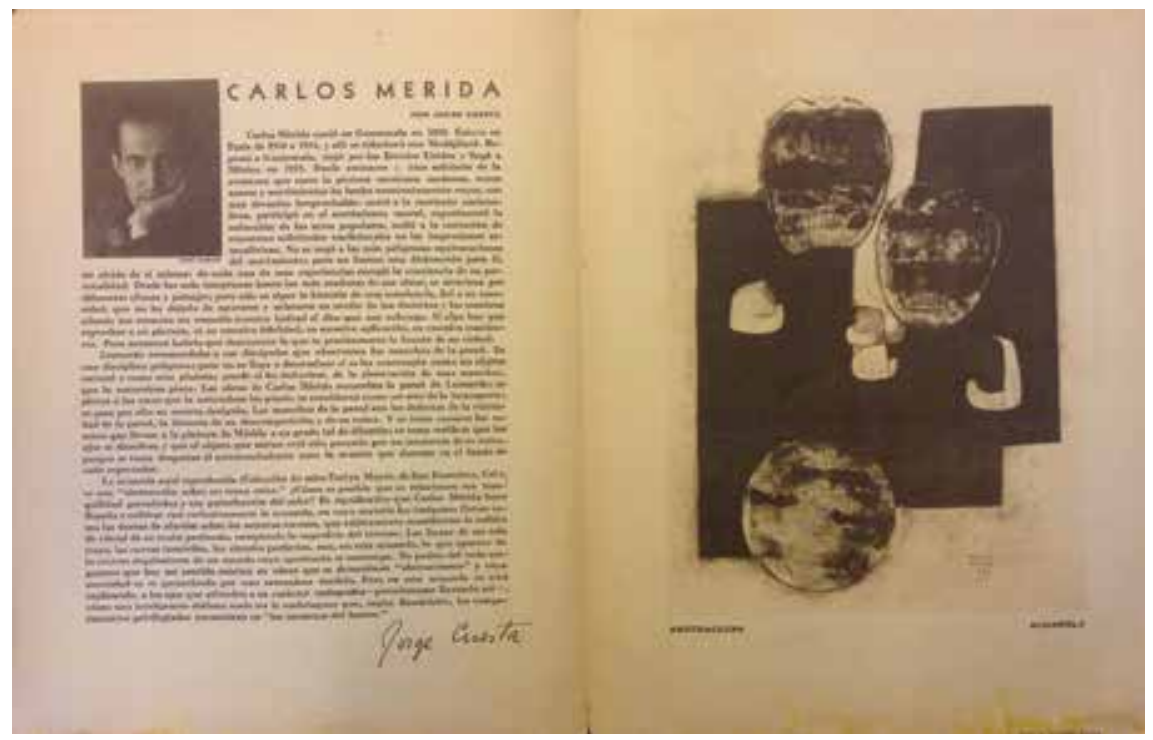

2. Páginas interiores de Galería de Pintores Modernos Mexicanos, ca. 1934. Colección particular. Fotografía del autor. 
la portada, así como el anuncio al final del Boletín, variaban en cada número (véase figs. 7, 8, 9 y го).

En el cuarto año del Boletín se simplificó el diseño y los contenidos al eliminar la página que se doblaba al centro, y reducir el número de las notas no dedicadas al arte, pero se conservaron los artículos relativos a la cerveza y su publicidad (figs. II y I2).

Es a partir del quinto año cuando el Boletín, además de la tradicional sección escrita por Novo de "Estampas del México Viejo", incluye nuevas secciones fijas, como "Para las damas", apartado mensual de recetas de cocina (que incluían a la cerveza Carta Blanca como ingrediente) cuya responsable era Marichu; ${ }^{3}$ y la sección "Lugares que deben visitarse", patrocinado por la Asociación Mexicana de Automovilistas (AMA), para la cual se seleccionaban textos de la revista de turismo Mapa (véase figs. I3 y I4).

\section{Breve historia del Boletín}

Miguel Capistrán, en un artículo publicado en 201 en el suplemento cultural del diario Milenio, resumió la historia de dicha publicación, la cual vale la pena citar in extenso:

En vista de la cercanía que me proporcionaba el hecho de ser asistente de Novo, supe que en su faceta de publicista - téngase en cuenta que fue socio de la Agencia de Publicidad Augusto Elías - dirigió las campañas de promoción de los productos del Grupo Monterrey, entre cuyas empresas estaba la Cervecería Cuauhtémoc, fabricante de la cerveza Carta Blanca. Xavier Villaurrutia le aconsejó a Novo que considerara la utilidad de lanzar una campańa que aportara conocimientos de una manera atractiva. Para ello propuso una serie de folletos que difundieran la obra de los creadores de la moderna pintura mexicana que ya ocupaban un sitio en el extranjero. El mensaje comercial llegaría de forma aceptable al público y, consecuentemente, la compañía embotelladora obtendría una imagen de respetabilidad y reconocimiento.

La propuesta de Villaurrutia no tomó a Novo por sorpresa, que sabía del interés que su amigo y colega tenía por el arte en general y, muy particularmente, por la

3. Seudónimo de la española María Aguilar de Carbia, quien desde finales de los años treinta escribió en México varios libros de recetas de cocina que fueron muy populares entre las amas de casa desde entonces hasta la década de los años ochenta. 


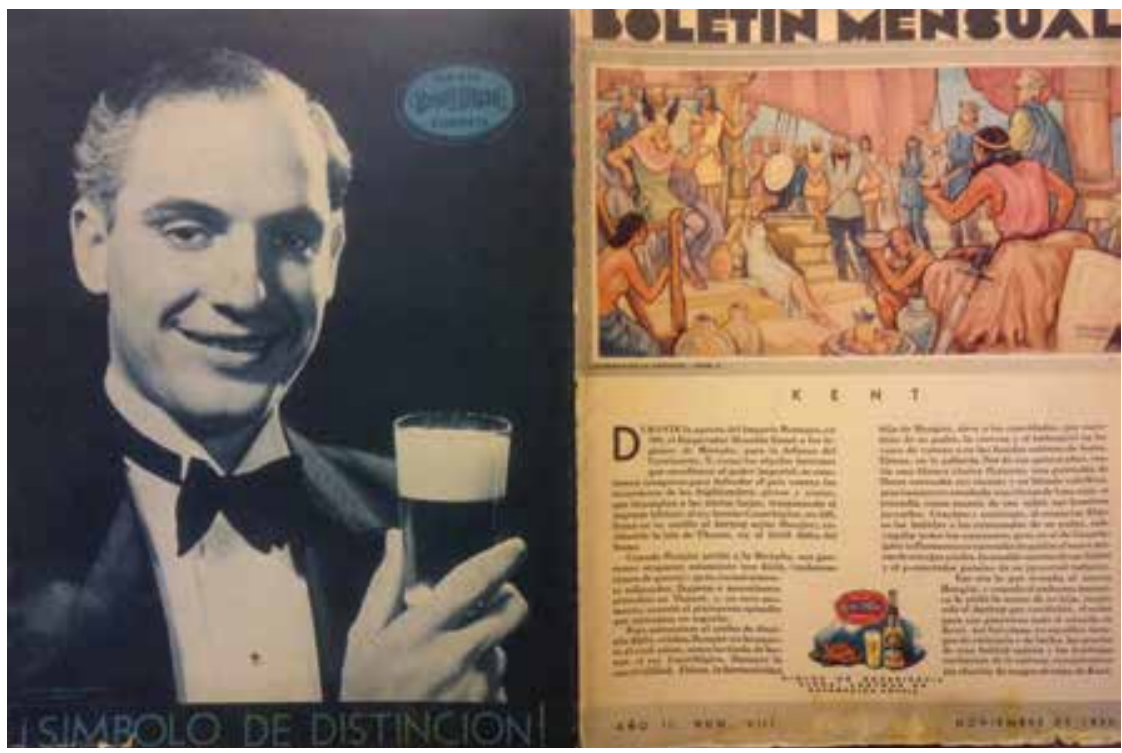

3. Contraportada y portada del Boletín Mensual Carta Blanca, noviembre de 1935. Colección particular. Fotografía del autor.

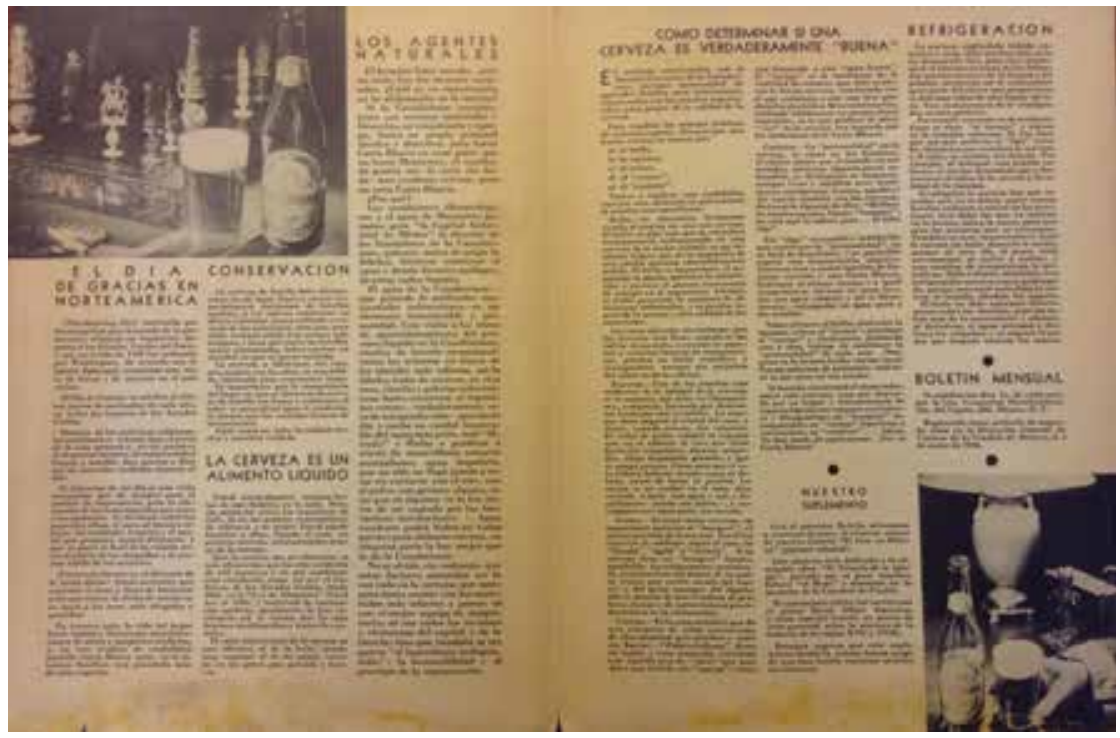

4. Reverso de la portada y contraportada del Boletín Mensual Carta Blanca, noviembre de 1935. Colección particular. Fotografía del autor. 
nueva pintura mexicana. Novo sabía también que Villaurrutia había incitado a varios artistas plásticos a incursionar en el terreno de la escenografía, que promovió con entusiasmo la creación de una de las primeras galerías de arte privadas en México y organizó exposiciones de carácter individual y colectivo. Los tycoons regiomontanos apoyaron la idea y un equipo de "creativos" se puso a trabajar de inmediato. En sus comienzos, el Boletín Mensual estuvo bajo la responsabilidad de los pintores Carlos Mérida y Carlos Orozco Romero. Villaurrutia intervino en la elección de los pintores y colaboró con frecuencia. Así pues, con el título Galería de pintores modernos mexicanos, en 1934 nació la campaña. [...] Sospecho que este esfuerzo de divulgación llegó a su fin en abril de 1939. Lo digo porque, a pesar de mis pesquisas, no he podido hallar un número posterior a esta fecha. El propio Novo no recordaba con precisión el dato a este respecto, cuando hablamos del asunto en 1967.4

Este Boletín no fue simplemente una feliz ocurrencia de Novo y Villaurrutia, sino una continuación de las actividades mediante las cuales la Cervecería Cuauhtémoc promovió el arte moderno en México. En enero de 1931, la empresa abrió la Galería Carta Blanca en la avenida Madero de la Ciudad de México, con una exposición de ocho pintores mexicanos (Carlos Mérida, Carlos Orozco Romero, Agustín Lazo, Fermín Revueltas, Jean Charlot, Tamiji Kitagawa, Roberto Montenegro y David Alfaro Siqueiros) organizada por Carlos Orozco Romero y Carlos Mérida. El discurso inaugural, sobre el arte moderno, corrió a cargo de Xavier Villaurrutia, 5 y José Gorostiza hizo una reseña muy crítica de la exposición, la cual fue publicada en El Universal Ilustrado en febrero de $1931 .{ }^{6} \mathrm{~A}$ su vez, esta exposición le daba continuidad en cierta forma a la labor realizada por Orozco Romero y Mérida, quienes entre 1929 y 1930 dirigieron la Galería del Teatro Nacional que se instaló en el edificio, entonces sin terminar que ahora es el Palacio de Bellas Artes, por encargo de la dirección de Acción Cívica del

4. Miguel Capistrán, “De cerveza, arte y publicidad”, Visor, núm. 43I, (2OII), 4, consultado el 29 de enero de 20I6, http://issuu.com/mileniodiariojalisco/docs/visor_oroct2oII.

5. Véase el prefacio a la invitación de dicha exposición, en: Aurelio de los Reyes, El nacimiento de ;Que viva México! (México: Universidad Nacional Autónoma de México-Instituto de Investigaciones Estéticas, 2006), 37I.

6. José Gorostiza, “Torre de señales: Una nueva sección a cargo de José Gorostiza”, El Universal Ilustrado: Un semanario mexicano con espíritu I4, núm. 717 (I93I): 32. Reproducido por International Center for the Arts of the Americas at the Museum of Fine Arts, Houston, Documents of 2oth-century Latin American and Latino Art, consultado el 28 de enero de 20I6, http://icaadocs. mfah.org/icaadocs/THEARCHIVE/FullRecord/tabid/88/doc/760487/language/en-us/Default.aspx. 


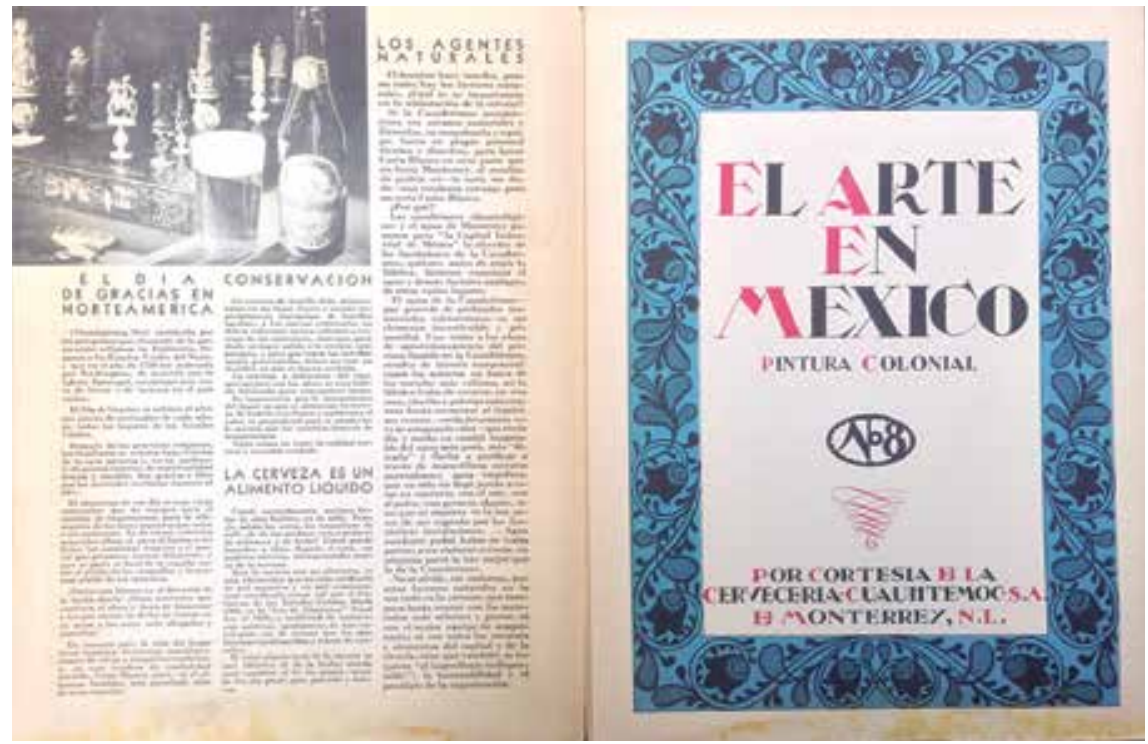

5. Contraportada y portada del anexo del Boletín Mensual Carta Blanca, noviembre de 1935. Colección particular. Fotografía del autor.

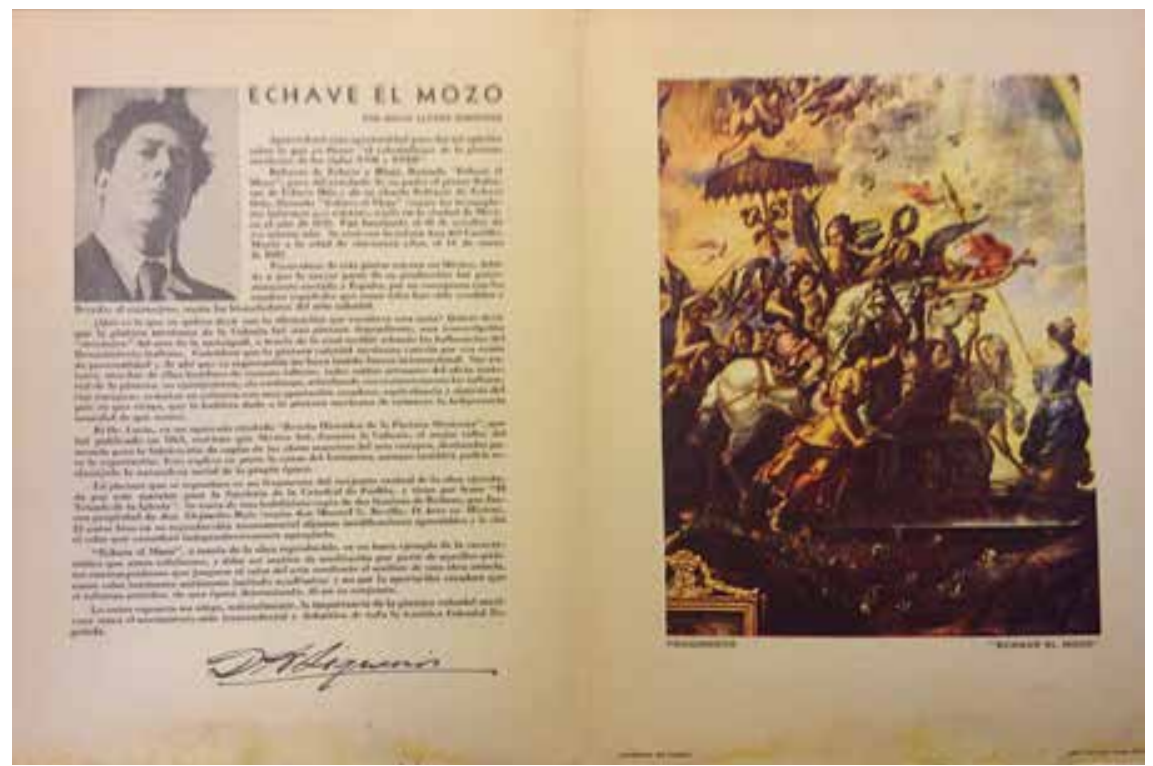

6. Páginas interiores del anexo del Boletín Mensual Carta Blanca, noviembre de 1935. Colección particular. Fotografía del autor. 
Departamento del Distrito Federal.7 Mérida y Orozco Romero compartieron la responsabilidad de la parte artística del Boletin durante 1934, y hasta el número cinco del segundo año, correspondiente a agosto de 1935. Posteriormente, fue Orozco Romero quien se encargó de realizar esta labor.

La crítica de arte realizada por escritores y artistas plásticos en revistas como el Boletín Mensual Carta Blanca reforzaba la idea de Villaurrutia, seguramente compartida por otros miembros del "Grupo sin grupo", ${ }^{8}$ de las afinidades estéticas existentes entre el poeta y el pintor, y las formas poéticas y las plásticas, misma que desarrolló Villaurrutia en una conferencia introductoria a la Exposición de Arte Moderno de 1932..$^{9}$ Por ello, no es de extrańar que muchos de los que antes participaron en las revistas Contemporáneos (1928-193I) de Novo y Villaurrutia, y Examen (1932) de Jorge Cuesta, se unieran a esta nueva labor cultural.

De hecho, Capistrán señala que con este Boletín se demuestra que la colaboración del grupo Contemporáneos fue mucho más allá de I932, así como que dicho grupo "convocó a muchos artistas que suelen olvidarse cuando nos referimos a los proyectos multidisciplinarios de Ulises y Contemporáneos — Rufino Tamayo, Agustín Lazo, Julio Castellanos, Carlos Orozco Romero, Manuel Rodríguez Lozano, Carlos González-”. ${ }^{10}$ En este sentido sería relevante plantear a futuro el análisis integral del Boletín, en el contexto del de las redes intelectuales que permitieron la colaboración, seguramente pagada, de estos artistas y escritores en el proyecto, así como la publicidad alcanzada por los artistas en la incorporación de pintores contemporáneos en la serie.

\section{La publicación del Boletín en el contexto de la politica cultural del Estado mexicano de la primera mitad del siglo XX}

La publicación del Boletín así como sus esfuerzos por combinar la apreciación conjunta del arte, la literatura y la gastronomía también deben analizarse

7. Justino Fernández, El arte moderno en México. Breve historia siglos XIX y XX, pról. Manuel Toussaint (México: Antigua Librería Robredo, José Porrúa e hijos, 1937), 312-313.

8. Nombre con el que también se conoce al grupo literario Contemporáneos. Véase José Luis Martínez, "El momento literario de los contemporáneos", consultado el 28 de enero de 20I6, http://www.letraslibres.com/revista/convivio/el-momento-literario-de-los-contemporaneos.

9. Xavier Villaurrutia, "Pintura sin mancha", Textos y pretextos. Literatura-Drama-Pintura (México: La Casa de España en México, 1940), 205-206.

Io. Capistrán, "De cerveza, arte y publicidad", 5. 
DOI: http://dx.doi.org/10.22201/iie.18703062e.2017.1.2594

7. Portada del Boletín Mensual Carta Blanca, marzo de 1936. Colección particular. Fotografía del autor.

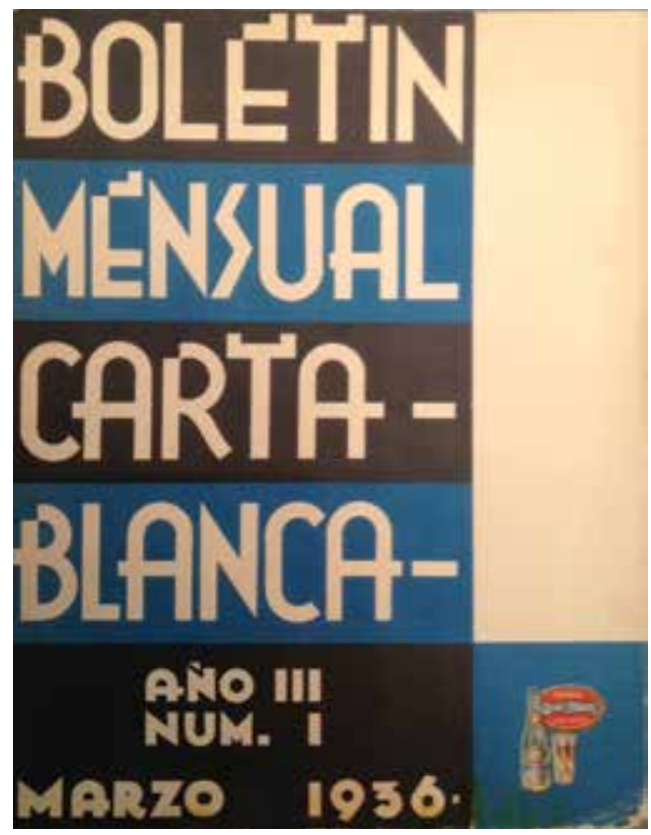

8. Contraportada del Boletín Mensual Carta Blanca, marzo de 1936. Colección particular.

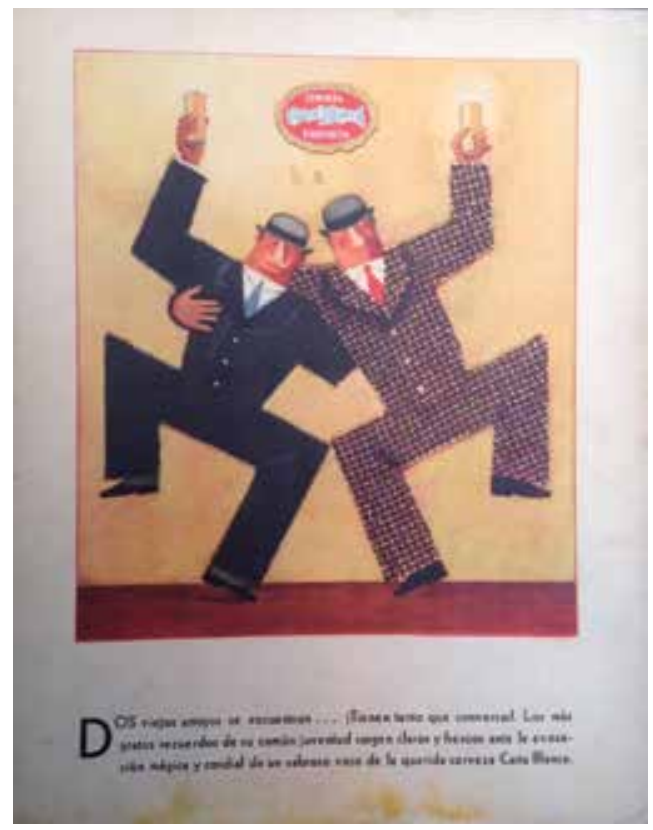

Fotografía del autor. 
en el contexto de la visión de modernización cultural del país, que promovió el Estado mexicano a principios del siglo xx. La participación de los escritores y los artistas plásticos como críticos de arte fue importante como elemento de validación de esta nueva concepción de la ética y la estética compartida hasta cierto punto por el Estado y las vanguardias. Recordemos que para José Vasconcelos (con quien colaboraron en la Secretaría de Educación Pública de México muchos de los escritores de Contemporáneos y del Boletín Mensual Carta Blanca cuando éste fue secretario) el fin de toda educación humana debía tener como culminación la formación estética del individuo. En el prólogo de La raza cósmica Vasconcelos hizo explícita esta relación entre ética y estética, al proponer que el estado más alto que alcanzaría la humanidad sería el espiritual o estético, en el que "la orientación de la conducta no se buscará en la pobre razón, [...] se buscará en el sentimiento creador y en la belleza que convence". II Es posible que muchos de sus colaboradores también compartiesen este ideal y se dedicasen a difundir el arte para elevar la educación de las masas.

A partir de la consolidación en el poder del nuevo régimen político emanado de la Revolución mexicana durante la segunda década del siglo xx, una de las principales preocupaciones del Estado fue tratar de generar un proyecto cultural representativo de los ideales del nuevo régimen que ayudase a superar las diferencias étnicas, políticas y sociales que caracterizaban al país. En dicho proyecto se procuró incorporar no sólo lo tradicionalmente considerado como alta cultura, sino también lo popular y lo folclórico, con vistas a generar un patrimonio cultural nacionalista común a todos los mexicanos. ${ }^{\mathrm{I2}}$

Una de las estrategias seguidas para la promoción de este nuevo proyecto, en especial a partir del periodo comprendido entre 1920 y 1930, fue la difusión masiva de productos culturales que adquirieron una categoría simbólica, como fue el caso de la colección de autores clásicos publicada por la Secretaría de Educación Pública bajo el patrocinio de Vasconcelos, editada en grandes tirajes y distribuida de manera gratuita entre la población, o la promoción del

II. José Vasconcelos, La raza cósmica. Misión de la raza iberoamericana. Notas de viajes a la América del Sur (Madrid: Agencia Mundial de Librerías, I925), 27.

I2. Néstor García Canclini ha señalado que México representó el caso precursor de lo que después se volvería una tendencia en diversos países de América Latina: la generación de una cultura simbólica que pareciera reconciliar a las clases. Véase Nestor García Canclini, Los dilemas de las culturas populares latinoamericanas bajo la confluencia de tradición, modernidad y posmodernidad: el caso mexicano, ponencia presentada al seminario "The Debate on Post-Modernism in Latinamerica: Brasil, Mexico and Peru” (Texas: Universidad de Austin, 1988), 4. 


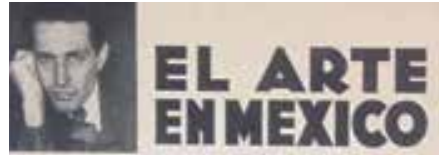

PEETER JANSZ POURBUS, el Viejo mes cuncer wavios

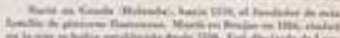

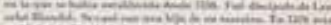

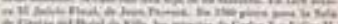

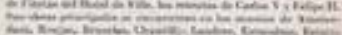

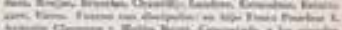

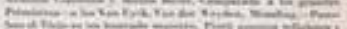

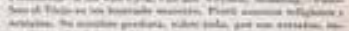

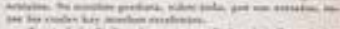

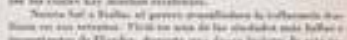

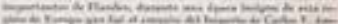

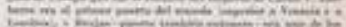

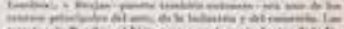

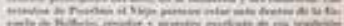

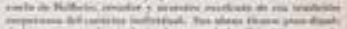

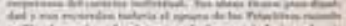
intein

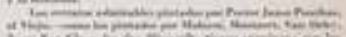

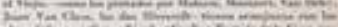

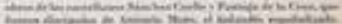

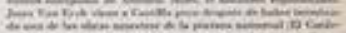

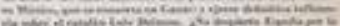

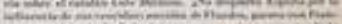

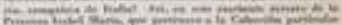

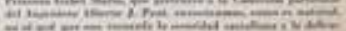

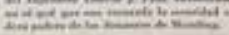

thene stivis.

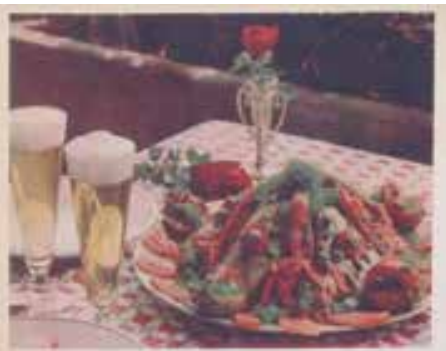

DEL CASINO ESPAÑOL DE MEXICO
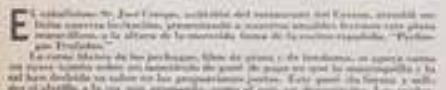

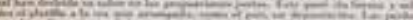

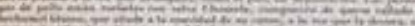

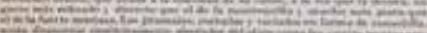

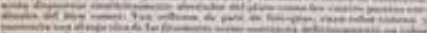
I

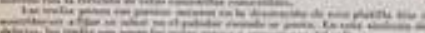

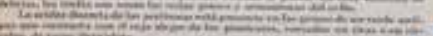

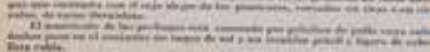
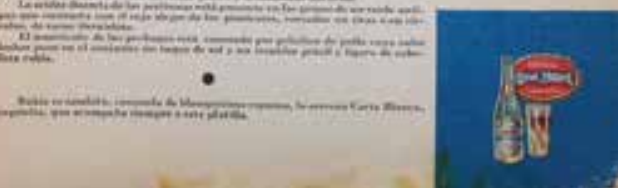

9. Páginas interiores del Boletín Mensual Carta Blanca, marzo de 1936. Colección particular. Fotografía del autor.

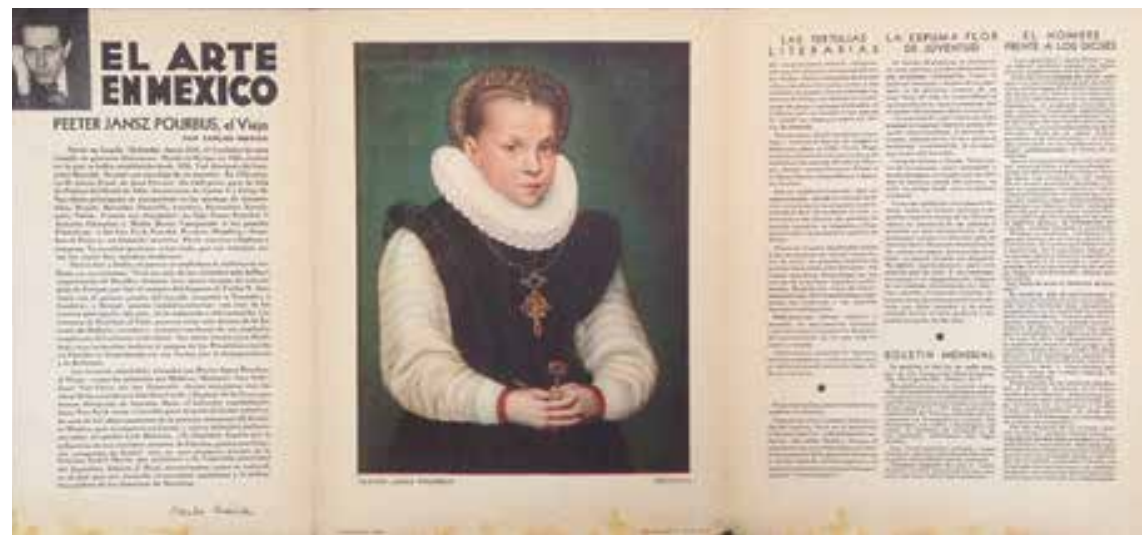

Io. Páginas interiores desplegadas del Boletín Mensual Carta Blanca, marzo de 1936. Colección particular. Fotografía del autor. 
arte para el disfrute de las masas mediante el muralismo realizado en espacios públicos. Carlos Monsiváis afirma que entre 1930 y 1950 ocurrió la etapa más fecunda de la cultura popular urbana con el inicio de nuevas industrias culturales que buscaban incorporar al pueblo a este proyecto a través de los medios masivos de comunicación, ${ }^{13}$ como el cine, la radio y publicaciones periódicas como diarios y suplementos culturales.

Si bien es cierto que durante la década de los años veinte y treinta del siglo xx, la edición de libros, revistas y carteles encontró en el Estado mexicano posrevolucionario a uno de sus mayores patrocinadores, existieron varias publicaciones periódicas que se editaron de forma autónoma, o con recursos privados, por grupos interesados en una visión particular que buscaba incidir en la vida pública. En México, a partir de los años veinte del siglo pasado, diversos grupos de escritores y artistas que pertenecieron a distintos movimientos de vanguardia buscaron contribuir a la definición de lo que debería considerarse como parte de la cultura nacional. Para ello, desde los años treinta hicieron uso ya no de revistas culturales autofinanciadas de corto tiraje, sino de publicaciones periódicas patrocinadas por particulares y de medios masivos de comunicación, como los suplementos culturales de diferentes diarios y revistas. En ellos dieron cabida en sus páginas centrales al trabajo de artistas visuales de la época, de manera similar a como lo hacían revistas europeas (como por ejemplo Transition, de Eugene Jolas y Elliot Paul), integraban imágenes y crítica, y generaban con ello nuevos objetos culturales híbridos ${ }^{I 4}$ que servían a sus propósitos de difusión.

Para Esther Gabara, un ejemplo emblemático de estos objetos culturales híbridos en los que se combina la reflexión crítica con el uso de las reproducciones fotográficas y el diseño gráfico lo constituye precisamente el Boletín Mensual Carta Blanca. Gabara también ha señalado que en México los movimientos literarios de vanguardia participaron activamente en las versiones tempranas de los medios de comunicación masiva y contribuyeron con ello a la

13. Carlos Monsiváis, "Junto contigo le doy un aplauso al placer y al amor", Textos, Revista Bimestral del Departamento de Bellas Artes del Gobierno de Jalisco 2, núms. 9-Io (I975): 45.

I4. García Canclini define la hibridación como "procesos socioculturales en los que estructuras o prácticas discretas, que existían en forma separada, se combinan para generar nuevas estructuras, objetos y prácticas". Véase Nestor García Canclini, Hybrid Cultures. Strategies for Entering and Leaving Modernity, con una nueva introducción del autor y un prólogo de Renato Rosaldo (Mineápolis: University of Minnesota Press, 2005), XXV. 
DOI: http://dx.doi.org/10.22201/iie.18703062e.2017.1.2594

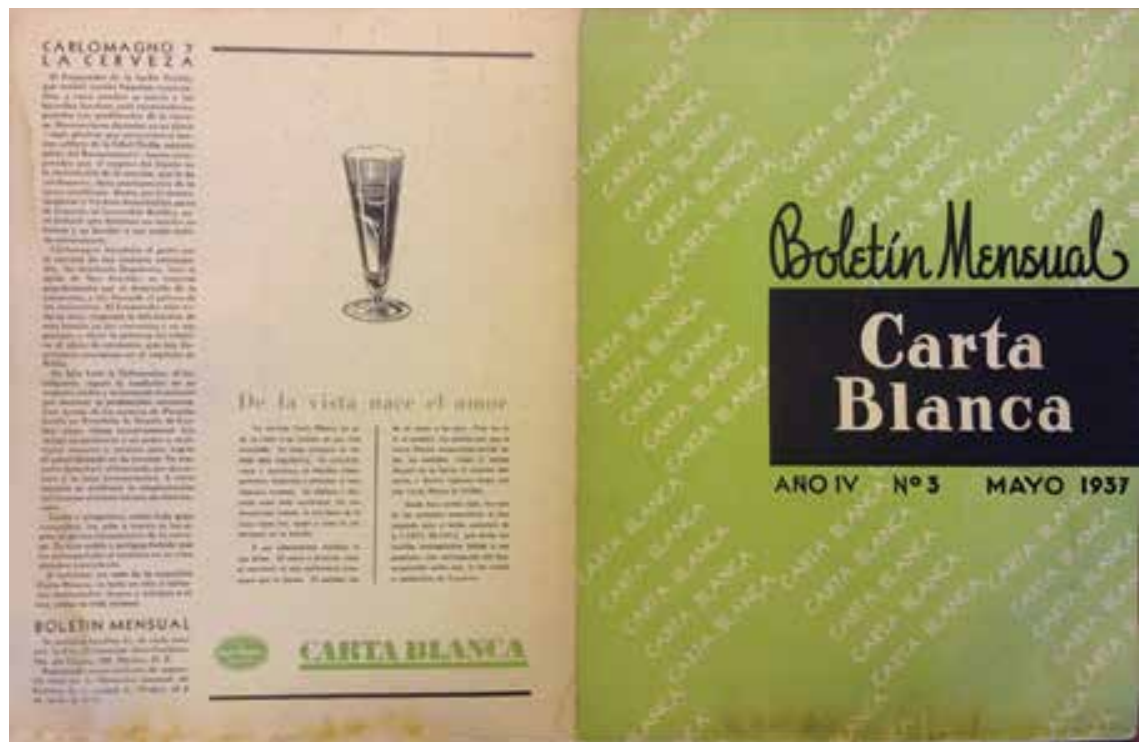

II. Contraportada y portada del Boletín Mensual Carta Blanca, mayo de 1937. Colección particular. Fotografía del autor.

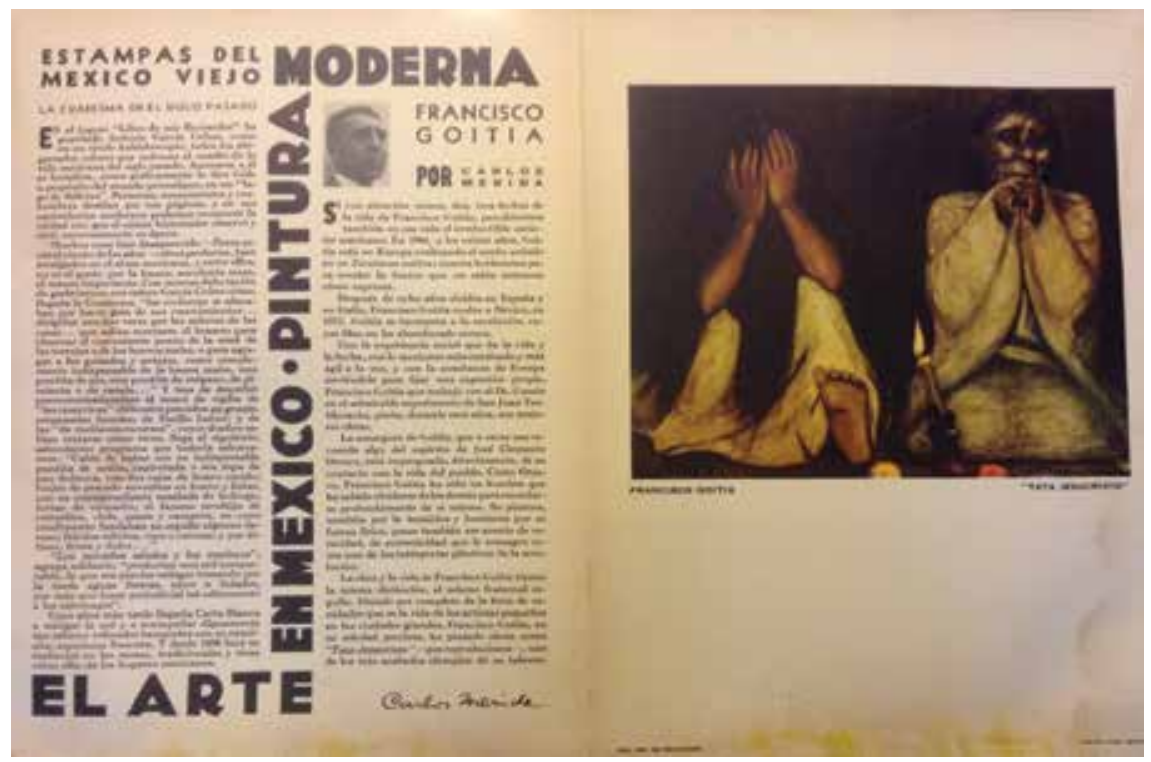

I2. Páginas interiores del Boletín Mensual Carta Blanca, mayo de 1937. Colección particular. Fotografía del autor. 
representación de una cultura urbana y nacionalista de masas. ${ }^{\text {I5 }}$ Pero además, partiendo de la fotografía y de las imágenes de que hicieron uso estos escritores y artistas de las vanguardias, Gabara propone que el novedoso empleo de fotografías y la idea de la representación a través de la imagen condujo a los artistas y escritores a producir trabajos en los que fusionaron sus ideas y meditaciones sobre la ética con experimentos estéticos que dieron lugar a lo que la autora llama el "ethos de la modernidad", es decir reflexiones sobre el qué y el cómo debe considerarse parte del sentido de comunidad y de la cultura nacional en el contexto de la modernidad. ${ }^{16}$

$\mathrm{Al}$ hablar de la sección dedicada a las recomendaciones turísticas que se incluyeron en el Boletin a partir de abril de 1938 en la sección "Lugares que deben visitarse", Gabara señala que el artista, en su función de aprendiz de turista, participó de manera directa en el desarrollo de una nueva estética de la modernidad, al visualizarse como alguien que se involucraba en la actividad que describía, y no como alguien ajeno a ella. ${ }^{17}$ De la misma forma, es de suponer que los artistas plásticos que participaron como críticos en el Boletín procuraron acercarse a las obras de los artistas coloniales, europeos y contemporáneos con ese mismo sentido de involucramiento, al reconocer aquellas técnicas y valores universales dignas de difundirse, en un proceso simultáneo de aproximación y distanciamiento de la obra plástica comentada, procurando acercar y divulgar al mismo tiempo la obra seleccionada a un público más amplio. Gabara señala que fue mediante esta participación activa en la creación de una cultura popular, que la modernidad estableció un puente entre la ética y la estética.

\section{Las múltiples funciones del Boletín}

En esta discusión no debe perderse de vista la naturaleza publicitaria y de difusión del Boletín. Si bien los escritores y artistas que participaron en las notas de dicha publicación expresaron en ocasiones su sentir sobre las implicaciones ideológicas de la pintura que reseñaban (como es el caso de Siqueiros en la nota que aquí se presenta), en general la publicación estaba planteada desde el inicio

15. Esther Gabara, Errant Modernism. The Ethos of Photography in Mexico and Brazil (Durham:

Duke University Press, 2008), I4I.

16. Gabara, Errant Modernism, I-2, 6.

I7. Gabara, Errant Modernism, I42. 


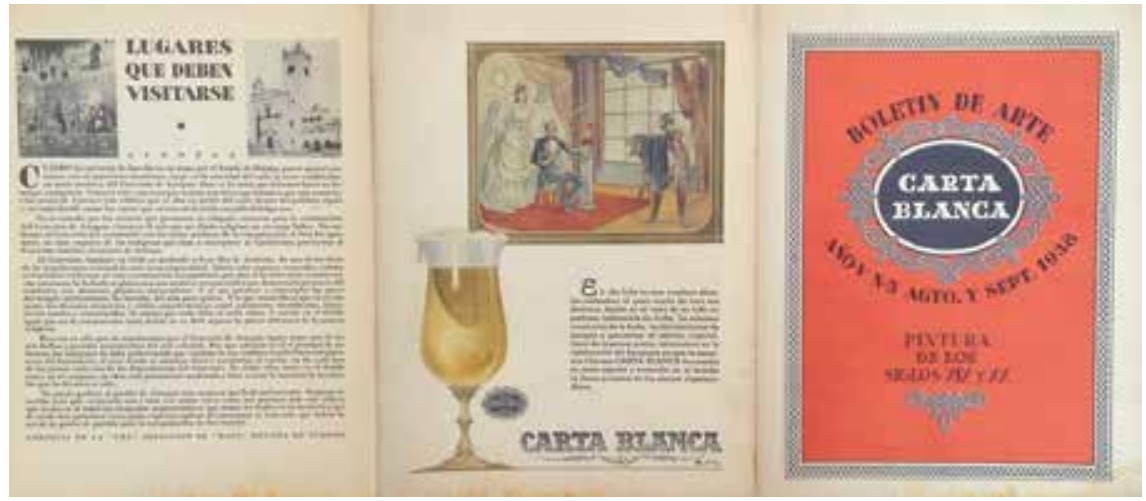

13. Contraportada, página central y portada del Boletín de Arte Carta Blanca, agosto-septiembre de 1938. Colección particular. Fotografía del autor.

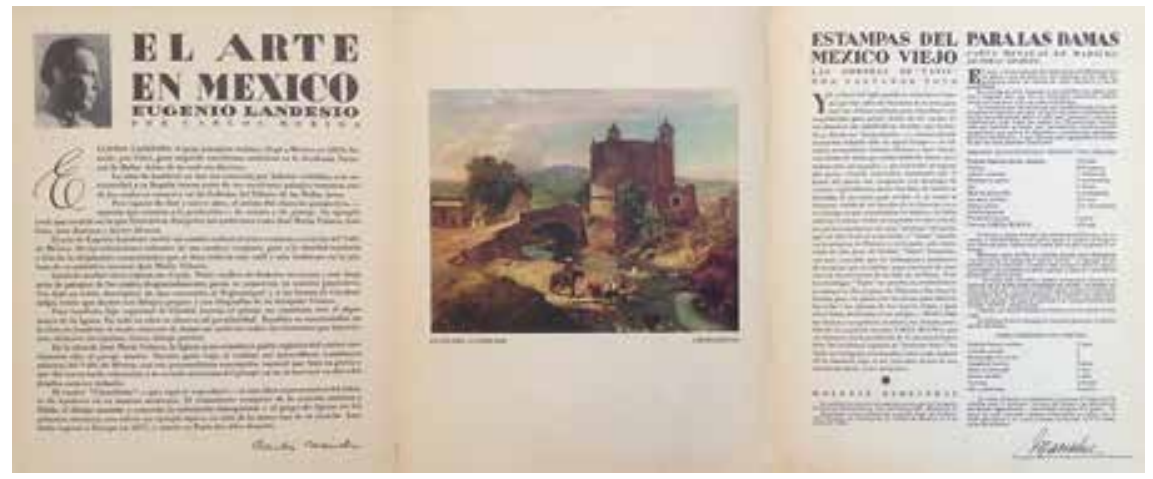

14. Páginas interiores del Boletín de Arte Carta Blanca, agosto-septiembre de 1938. Colección particular. Fotografía del autor.

como un formato divulgativo asociado abiertamente a una agencia publicitaria. Las notas sobre arte que incluía no pretendían ser exhaustivas ni presentar reflexiones teóricas profundas, sino ser breves ensayos dedicados a promover la difusión del arte entre la población de cierto nivel sociocultural. Por ello, varios de los ejemplos transcritos parecieran ser más una reseña históricobiográfica de los autores que el análisis de una obra específica. Si bien la presencia de la nota sobre arte y su correspondiente ilustración siempre ocupó el lugar central del Boletín, casi siempre iban acompañadas de otras notas diversas sobre múltiples temas de cultura general. Se trataba de pequeños artículos 
que fuesen atrayentes para unas incipientes clases media y alta urbanas con mayor poder adquisitivo y nuevos gustos en el comer y el beber. De hecho, a la publicidad de la cerveza siempre se le dedicó un espacio igual al de la imagen artística, así como otros artículos con frases y expresiones que asociaban beber cerveza con eventos sociales y el buen gusto en el vivir. La afición por el arte parecería estar presentada implícitamente en esta publicación como un complemento para las nuevas pretensiones de modernidad que traían aparejadas las nuevas condiciones socioeconómicas de la población. ${ }^{18}$

Tampoco debe soslayarse el hecho de que el Boletin era una empresa particular cuyos directivos también tenían intereses específicos al realizar la selección de obra y el encargo de las críticas, las cuales seguramente eran remuneradas. Como se señaló con anterioridad, sólo la primera serie del Boletín y los primeros cinco números de la segunda, los dirigieron en forma conjunta Orozco Romero y Mérida; el resto fue dirigido únicamente por Orozco Romero. El interés de Orozco Romero por dirigir el Boletín obedeció muy probablemente no sólo al deseo de promover una obra cultural, sino también de promocionar el arte mexicano dentro de un mercado artístico en desarrollo y figurar él mismo dentro del panorama de la crítica de arte en México, todo ello mediante

I8. El discurso contenido en estos boletines apunta hacia la legitimación de un gusto, cuya posesión a su vez asigna estatus a quienes degustan la cerveza junto con los platillos sugeridos en un ambiente refinado, en el que el arte juega un papel central. Estamos frente a un campo en el que se combina lo artístico con lo culinario y cuyos discursos se dirigen principalmente a las familias urbanas, y de manera específica a un sector de la población en particular, el de la naciente clase media, que hasta principios del siglo xx son quienes comienzan a acceder con mayor fuerza al capital escolar hasta entonces reservado a las clases más altas. La posibilidad de apropiarse del saber contenido en publicaciones como las que aquí se reseñan les ofrece la opción de adquirir un capital cultural basado en saberes reconocidos, y con ello acceder a la asignación de un estatus positivo que les otorgue lo que Pierre Bourdieu llama un "título de nobleza cultural”. Bourdieu habla de este "efecto de asignación de estatus, positivo (ennoblecimiento) o negativo (estigmatización), que todo grupo produce al asignar a los individuos a unas clases jerarquizadas. A diferencia de los poseedores de un capital cultural desprovisto de certificación académica, que siempre pueden someterse a pruebas, porque no son más que lo que hacen, simples hijos de sus obras culturales, los poseedores de títulos de nobleza cultural — semejantes en esto a los poseedores de títulos nobiliarios, en los que el ser, definido por la fidelidad a una sangre, a un suelo, a una raza, a un pasado, a una patria, a una tradición, es irreductible a un hacer, a una capacidad, a una función- no tienen más que ser lo que son, porque todas sus prácticas valen lo que vale su autor, al ser la afirmación y la perpetuación de la esencia en virtud de la cual se realizan”. Véase Pierre Bourdieu, La distinción. Criterio y bases sociales del gusto, trad. María del Carmen Ruiz de Elvira (Madrid: Taurus, 1998), 20-2I. 
tres vertientes: coadyuvar en la selección de los artistas a comentar, haciendo uso de su buen ojo como maestro de pintura; promover por medio del Boletín la obra de los artistas mexicanos entre potenciales coleccionistas de una clase alta que comenzaba a despegar; y abrir la puerta a los más diversos puntos de vista en materia artística, buscando promover el desarrollo de la crítica de arte. Al hablar de la pintura de Orozco Romero, Inés Amor señala que "sus intereses fueron diferentes de la escuela mexicana; era más frívolo, le interesaba el éxito social, el éxito de venta". ${ }^{19}$ Este interés por posicionar la obra de arte en el mercado combinando la publicidad con el arte también lo señalaron otros contemporáneos suyos. Justino Fernández mencionó que "Desde su regreso a México en 1925 no ha dejado de estar activo en la pintura, mas también se ha ocupado en la divulgación del arte, y la serie de publicaciones del boletín mensual 'Carta Blanca' (1935-1938) dirigidas por él, que llevan reproducidas a color obras de pintores mexicanos, fue una muestra de su talento" ${ }^{20}$ Y Agustín Velázquez Chávez, al mencionar su labor en México mencionó que: "ha publicado, en compañía de Carlos Mérida, transformando en una obra cultural un trabajo de propaganda, varios cuadernos sobre la obra de pintores modernos mexicanos antiguos y contemporáneos (Galería de Pintores Modernos Mexicanos, El Arte en México. Pintura Colonial; Publicaciones de la Cervecería Cuauhtémoc S.A. México, 1933-1935)." ${ }^{21}$

Un ejemplo de la forma en que el Boletin trató de contribuir a revalorar las colecciones de arte privadas en México lo constituye la serie Pintura Europea de los Siglos XIV y XV en Colecciones de México (reseñada entre 1936 y 1937), dedicada a comentar casi exclusivamente piezas de la segunda colección Pani, propiedad del ingeniero, funcionario y diplomático Alberto J. Pani, ${ }^{22}$ quien unos años después, entre 1938 y I940, trató de vender sin éxito dicha colección al gobierno de México. De un total de I2 obras que comprendía la serie, ı per-

19. Jorge Alberto Manrique y Teresa del Conde, Una mujer en el arte mexicano. Memorias de Inés Amor (México: Universidad Nacional Autónoma de México, 1987), 73.

20. Justino Fernández, Arte moderno y contemporáneo de México (México: Imprenta Universitaria, 1952), 444 .

2I. Agustín Velázquez Chávez, Índice de la pintura mexicana contemporánea (México: Ediciones Arte Mexicano, 1935), I27.

22. Luis Cardoza y Aragón, en su comentario sobre la obra Cabeza de Apóstol, de Jacques Jordaens, señalaba, por ejemplo, que esta pieza "había sido adquirida por el Señor Ingeniero Alberto J. Pani, entre un lote de pinturas que perteneció a la Colección Warneck, vendidas por el barón León Pitteurs Hugaert d'Orange [...]". Véase Luis Cardoza y Aragón, "Jacques Jordaens", Boletín Mensual Carta Blanca III, núm. III (1936): s.p. 
tenecían a la colección Pani; las otras dos obras comentadas formaban parte de la colección del también funcionario y diplomático Genaro Estrada. Incluso uno de los comentadores de esta serie fue el pintor Roberto Montenegro, quien fungió como experto certificador de la primera colección Pani que se vendió en 1926 al gobierno de México y que ahora forma parte de los acervos del Museo de San Carlos en la Ciudad de México. ${ }^{23}$ Ana Garduño menciona que la forma en que se llevó a cabo la primera venta y los reproches que se le hicieron por las "exageradas atribuciones autorales y la inconsistencia de autenticidades $[\ldots]$ provocó sospechas sobre la originalidad de muchas de ellas y se le percibió como un coleccionista si no malintencionado, al menos cándido e inexperto". ${ }^{24}$ Convocar a pintores y escritores de prestigio para que comentaran algunas de las piezas de su segunda colección en el Boletín fue quizá una manera de reivindicar su talento y buen ojo como coleccionista, y de mejorar también la posible valoración de su colección. Samuel Gordon ha señalado también el caso del poeta Carlos Pellicer y su artículo del Boletín de febrero de 1937 dedicado dentro de esta misma serie al pintor Guido Reni. En una carta fechada en 1927 dirigida al entonces cónsul de México en París, Alberto J. Pani, Pellicer había señalado su desagrado ("respetuosa repugnancia") por las obras de Caracci y de Reni. Sin embargo, en 1937 cuando se le invita a opinar sobre una obra de Reni perteneciente a la colección de su amigo Genaro Estrada (con quien Pellicer estaba agradecido por salvarlo de la cárcel y de un fusilamiento injusto), su juicio sobre la obra se atempera sin dejar de ser negativo, e incluso dedica a la pieza propiedad de su amigo algunos elogios, ${ }^{25} \mathrm{y}$ cierra su crítica con la elegante frase: "El cuadro que reproducimos muestra más las virtudes que los defectos de su autor". ${ }^{26}$

23. Para la historia de la venta de la primera colección Pani y otros avatares de este coleccionista, véase Ana Garduño, "Patrimonialismo y poder: Alberto J. Pani, coleccionista institucional (1917-1934)”, en Víctor Mínguez, ed., Las artes y la arquitectura del poder (Castelló de la Plana: Publicaciones de la Universitat Jaume I, D.L., 2013), I085-I097, consultado el 28 de enero de 2016, https://bellasartes-mx.academia.edu/AnaGardu\%C3\%Bio. Sobre Montenegro, véase también el artículo del pintor Rodríguez Lozano, "La pintura y los intereses creados", en Manuel Rodríguez Lozano, Pensamiento y pintura (México: Imprenta Universitaria, 1960), I35-I39.

24. Garduño, "Patrimonialismo y poder", I086-I087.

25. Samuel Gordon y Fernando Rodríguez, "N’el mezzo del cammin di nostra vita. Carlos Pellicer: 1937", Literatura Mexicana 8, núm. I (1997): 9-IO.

26. Carlos Pellicer, "Guido Reni”, Boletín Mensual Carta Blanca, año III, núm. XII (I937): s.p. 


\section{Los artistas plásticos como críticos de arte en el Boletín}

A continuación se presentan ocho colaboraciones de artistas plásticos que elaboraron notas de crítica de arte en el Boletín. Representan prácticamente todos los textos de artistas plásticos publicados a lo largo de la historia editorial del folleto, con excepción del artículo de Carlos Mérida sobre Fermín Revueltas (de julio de 1934) al que no se pudo tener acceso. Estas notas complementan los trabajos de rescate de las reseñas elaboradas por los escritores Novo, Villaurrutia, Cuesta y Gorostiza, y que han sido publicadas con anterioridad en las ediciones de sus obras completas. Las ocho notas que presento no se habían vuelto a editar y las realizaron David Alfaro Siqueiros, Carlos Mérida, Carlos Orozco Romero y Roberto Montenegro, quienes participaron como críticos en el proyecto de Orozco Romero entre 1935 y 1938.

Para realizar la selección de notas que abordo en este artículo, tuve acceso a una colección de 42 números pertenecientes originalmente al pintor jalisciense Francisco Rodríguez "Caracalla" (1907-1989). ${ }^{27}$ A partir de dicha colección y de información proveniente del catálogo público en línea de la Biblioteca Francisco Xavier Clavigero de la Universidad Iberoamericana (que posee la colección más completa del Boletín) se hizo una relación de los contenidos de la revista referentes a las notas sobre crítica de arte, que se presentan en el cuadro I como anexo al final de esta nota.

Destaca entre ellas la primera nota de Alfaro Siqueiros sobre el pintor Echave el Mozo, ya que en ella expone tempranamente por escrito su idea del colonialismo de la pintura latinoamericana hasta antes del siglo $\mathrm{xx}$, y que más adelante desarrolló con mayor amplitud en algunas de los artículos recopila-

27. Francisco Rodríguez (conocido como "Caracalla") fue un importante protagonista de la pintura en Jalisco durante el siglo xx. Fundó en Guadalajara en 1936 la Academia de Artes Plásticas Evolución, fue ayudante de José Clemente Orozco en los murales de la Universidad, del Palacio de Gobierno y en una parte de la cúpula del Hospicio Cabañas. En la Ciudad de México colaboró en la fundación de la Galería de Arte Moderno, participando en su inauguración en una muestra colectiva con Jesús Guerrero Galván, Jorge González Camarena, Raúl Anguiano, Juan Soriano, Manuel González Serrano y Guillermo Meza. Véase Guillermo Ramírez Godoy y Arturo Camacho Becerra, Cuatro siglos de pintura jalisciense (Guadalajara: Cámara Nacional de Comercio de Guadalajara, I996), I00-IOI. Se dice que su apodo provenía de la semejanza de su perfil con una medalla romana en la que estaba representado el busto del emperador Caracalla. A finales de la década de 2000 su viuda, Lilia Lomelí, puso a la venta varias piezas de su biblioteca, entre las que se encontraban los ejemplares del citado Boletín, y que ahora forman parte de la biblioteca personal del autor de este artículo. 
dos en las páginas de su obra No hay más ruta que la nuestra. ${ }^{28}$ En cambio, las notas de Mérida, Orozco Romero y Montenegro dedicadas a la pintura de los siglos xIV y xV son más convencionales y buscan señalar las características técnicas y compositivas de las obras reseñadas y los méritos intrínsecos que las hacen dignas de estar incluidas en la colección Pani. Los artículos de Mérida referentes a Goitia, Antonio Ruiz y Landesio, y el de Siqueiros dedicado a Orozco Romero, muestran profundo conocimiento del oficio al analizar la obra de otro colega y expresan una interesante comprensión del trabajo ajeno.

\section{A manera de conclusión}

A partir de lo visto a lo largo de este ensayo, destaca la necesidad de realizar una aproximación compleja al formato de divulgación y a los contenidos que caracterizaron al Boletín Mensual Carta Blanca, incluyendo el diseño, las imágenes y otros artículos no necesariamente vinculados a la reseña, pero que contextualizan a cada número, lo que permitiría colocar al Boletín en perspectiva, así como abrir espacios de análisis e intercambios con otras rutas de la historia del arte en México.

En este sentido, la incorporación de la prensa como objeto de estudio, y dentro de ella las ediciones de carácter publicitario está apenas en sus inicios como parte de la investigación actual sobre la historia del arte en México. Por ello el tema de un boletín como el reseñado en esta nota puede ser de interés para futuros trabajos sobre recuperación y valoración de otras fuentes para la historia del arte en México. Vale la pena rescatar estos proyectos editoriales que lograron mantenerse en circulación durante varios ańos, y destacar los intereses que perseguían y sus aportaciones a la escena artística mexicana.

28. David Alfaro Siqueiros, No hay más ruta que la nuestra. Importancia nacional e internacional de la pintura mexicana moderna. El primer brote de reforma profunda en las artes plásticas del mundo contemporáneo. (Recopilación de diez artículos publicados en las revistas "Hoy" y "Mañana" y dos en el diario "El Nacional", de la Ciudad de México) (México: s.p.i., 1945). 


\section{Anexo documental \\ "Echave el mozo", por David Alfaro Siqueiros ${ }^{29}$}

Aprovecharé esta oportunidad para dar mi opinión sobre lo que yo llamo "el colonialismo de la pintura mexicana de los siglos XVII y XVIII".

Baltasar de Echave y Rioja, llamado "'Echave el Mozo", para diferenciarlo de su padre el pintor Baltasar de Echave Ibía y de su abuelo Baltasar de Echave Orio, llamado "Echave el Viejo" (según los incompletos informes que existen), nació en la ciudad de México el año de i632. Fue bautizado el 30 de octubre de ese mismo año. Se casó con la señora Ana del Castillo. Murió a la edad de cincuenta años, el I4 de enero de I682.

Pocas obras de este pintor existen en México, debido a que la mayor parte de su producción fue posteriormente enviada a España, por su semejanza con los cuadros espańoles que como tales han sido vendidos y llevados al extranjero, según los historiadores del arte colonial.

¿Qué es lo que yo quiero decir con la afirmación que encabeza esta nota? Quiero decir que la pintura mexicana de la colonia fue una pintura dependiente, una transcripción "mecánica" del arte de la metrópoli, a través de la cual recibió además las influencias del Renacimiento italiano. Considero que la pintura colonial mexicana careció por esa razón de personalidad y de ahí que su repercusión no haya tenido fuerza internacional. Sus autores, muchos de ellos hombres de enorme talento, todos sabios artesanos del oficio material de la pintura, no consiguieron, sin embargo, asimilando convenientemente las influencias europeas, rematar su esfuerzo con una aportación creadora, equivalencia y síntesis del país en que vivían, que le hubiera dado a la pintura mexicana de entonces la beligerancia mundial de que carece.

El Dr. Lucio, en un opúsculo titulado "Reseña Histórica de la Pintura Mexicana", que fue publicado en I864, sostiene que México fue, durante la colonia, el mejor taller del mundo para la fabricación de copias de las obras maestras del arte europeo, destinadas para la exportación. Esto explica en parte la causa del fenómeno, aunque también podría esclarecerlo la naturaleza social de la propia época.

La pintura que se reproduce es un fragmento del conjunto central de la obra ejecutada por este maestro para la Sacristía de la Catedral de Puebla, y tiene

29. David Alfaro Siqueiros, "Echave el Mozo", Boletín Mensual Carta Blanca II, núm. VIII (I935): s.p. 
por lema "El Triunfo de la Iglesia". Se trata de una habilísima copia de dos láminas de Rubens, que fueron propiedad de don Alejandro Ruiz (según don Manuel G. Revilla, "El Arte en México"). El autor hizo en su reproducción monumental algunas modificaciones apreciables y le dio el color que consideró independientemente apropiado.

"Echave el Mozo", a través de la obra reproducida, es un buen ejemplo de la característica que antes señalamos, y debe ser motivo de meditación por parte de aquellos artistas contemporáneos que juzguen el valor del arte mediante el análisis de una obra aislada, como valor intrínseco autónomo (método académico) y no por la aportación creadora que el esfuerzo artístico, de una época determinada, dé en su conjunto.

Lo antes expuesto no niega, naturalmente, la importancia de la pintura colonial mexicana como el movimiento más trascendental y definitivo de toda la América Colonial Española.

\section{“Peeter Jansz Pourbus El Viejo”, por Carlos Mérida ${ }^{30}$}

Nació en Gouda (Holanda), hacia 1510, el fundador de esta familia de pintores flamencos. Murió en Brujas en 1584 , ciudad en la que se había establecido desde 1538. Fue discípulo de Lancelot Blondel. Se casó con una hija de su maestro. En 1556 retoca El Juicio Final, de Jean Prevost. En 1560 pinta para la Sala de Fiestas del Hotel de Ville, los retratos de Carlos V y Felipe II. Sus obras principales se encuentran en los museos de Ámsterdam, Brujas, Bruselas, Chantilly, Londres, Estocolmo, Estuttgart, Viena. Fueron sus discípulos: su hijo Franz Pourbus I, Antonio Claessens y Hubin Bover. Comparado a los grandes Primitivos —a los Van Eyck, Van der Weyden, Memling_, Pourbus el Viejo es un honrado maestro. Pintó asuntos religiosos y retratos. Su nombre perdura, sobre todo, por sus retratos, entre los cuales hay muchos excelentes.

Nunca fue a Italia, ni parece avasalladora la influencia italiana en sus retratos. Vivió en una de las ciudades más bellas e importantes de Flandes, durante una época insigne de esta región de Europa que fue el corazón del Imperio de Carlos V. Amberes era el primer puerto del mundo (superior a Venecia y a Londres), y Brujas — puerto también entonces— era uno de los centros principales

30. Carlos Mérida, "Peeter Jansz Pourbus El Viejo", Boletín Mensual Carta Blanca III, núm. I (1936): s.p. 
del arte, de la industria y del comercio. Los retratos de Pourbus el Viejo parecen estar más dentro de la Escuela de Holbein, creador y maestro excelente de esa tradición respetuosa del carácter individual. Sus obras tienen gran dignidad y nos recuerdan todavía el apogeo de los Primitivos cuando ya Flandes se despedazaba en sus luchas por la Independencia y la Reforma.

Los retratos admirables pintados por Peeter Jansz Pourbus, el Viejo — como los pintados por Mabuse, Mostaert, Van Orley, Juan Van Cleve, los dos Mierevelt- tienen semejanza con las obras de los castellanos Sánchez Coello y Pantoja de la Cruz, que fueron discípulos de Antonio Moro, el holandés espanoolizado. Juan Van Eyck viene a Castilla poco después de haber terminado una de las obras maestras de la pintura universal "El Cordero Místico", que se conserva en Gante y ejerce definitiva influencia sobre el catalán Luis Dalmau. ¿No despierta España por la influencia de sus vencidos: anexión de Flandes, guerra con Francia, conquista de Italia? Así, en este excelente retrato de la Princesa Isabel María, que pertenece a la Colección particular del Ingeniero Alberto J. Pani, encontramos, como es natural, no sé qué que nos recuerda la severidad castellana y la delicadeza pulcra de los donantes de Memling.

\section{"Alvise Vivarini", por Carlos Orozco Romero ${ }^{31}$}

De la bizantina tradición ornamental, Venecia pasó a ser cuna de una de las más floridas Escuelas de Pintura del Renacimiento, hacia la segunda mitad del Siglo xv, bajo las influencias diversas de Siena y de Florencia, a través de Gentile da Fabriano, de Vittore Pisanello, de Antonello de Messina y de la Escuela de Padua, con el gran Mantegna. Dos centros surgen en Venecia: en la propia Ciudad, con la Familia Bellini, fundada por Jacobo — familia varias veces ilustrey en la Isla de Murano, con la Familia de los Vivarini, también de considerable importancia. El pintor más notable de la Escuela de Murano, fundada por Antonio Vivarini, fue Alvise Vivarini, nacido hacia 1446 y muerto hacia I5O2.

La Escuela fundada por Jacobo Bellini y la Escuela de Murano dieron a la pintura veneciana su verdadera profundidad plástica y la liberaron de su tendencia ornamental y complementaria. A partir de ellos, el arte veneciano refleja la inquietud social, las guerras casi permanentes, las revueltas y transformaciones de la vida opulenta y poderosa de Venecia. La biografía de la más hermosa 
de las ciudades se puede seguir en la gloria de su pintura. El arte siempre es una expresión de la inquietud colectiva: de la vida externa y de la vida íntima, y hasta de la vida secreta y recóndita del pueblo que lo engendra. Venecia da el concepto a esta pintura luminosa, jocunda, llena de imaginación y halago a los sentidos. Iniciadores y maestros, los Bellini y los Vivarini, hacen surgir una expresión nueva al buscar elementos constructivos en la propia naturaleza, al mismo tiempo que logran notables perfeccionamientos técnicos en el empleo de la pintura al óleo, acaso traída de Flandes por Antoniello de Messina.

Alvise Vivarini, maestro en el retrato, como buen discípulo del autor del retrato de "El Condottiero", que se conserva en el Museo del Louvre, y, también conocedor excelente de la enseñanza de Gentile da Fabriano y de la tradición lapidaria del Pisanello, no fue menos grande en su pintura religiosa. Notable fue su influencia: entre sus discípulos se cuentan artistas importantes: Cima de Conegliano, Marcos Basaiti, Bartolomé Montagna, Lorenzo Lotto...

¡Qué excelente muestra de su talento es el óleo que reproducimos - San Francisco de Asís - de la Colección del Ingeniero Alberto J. Pani! Difícil es precisar el encanto de esta obra: el paisaje lejano, de inmenso cielo diáfano, hace sobresalir, con fervor infinito, la imagen preciosa del Cristo medieval: noble cabeza y manos trágicas, delicadas y perfectas, entre un juego de paños tan sobrios y expresivos como las manos mismas, todo dentro de un ritmo organizado hasta en sus detalles mínimos.

\section{"Ovens Juriane", por Roberto Montenegro 32}

Pintor de historia, retratista y grabador, nace en Holstein en el año de I623. Llega a Ámsterdam en 1642 donde recibe el derecho de ciudadanía, siendo discípulo de Rembrandt. En I654 acompaña a la novia del Rey Carlos, hija del Duque de Holstein Goltorp, a Estocolmo y vuelve dos años más tarde a causa de la guerra entre Suecia y Dinamarca.

En Ámsterdam trabaja con Flinck y termina un cuadro de este pintor en el Hotel de Ville.

En I663 llega a Schleswig como pintor de la corte del Duque Christian Albert de Holstein Goltorp, donde trabaja en murales y plafones del castillo. Expulsado por la guerra, se establece definitivamente en Friedrichstadt.

32. Roberto Montenegro, “Ovens Juriane”, Boletín Mensual Carta Blanca III, núm. IX (1936): s.p. 
Graba retratos de personajes célebres y actualmente pueden verse sus cuadros y sus retratos en algunos de los principales museos de Europa.

Pintor de cuadros históricos y de retratos pudo sustraerse a la influencia de su maestro; para adquirir la de Van Dyck y la de Jordaens, y al fin fragua su personalidad cuando se establece en Ámsterdam pintando retratos de personajes de la corte. Cuaja su carácter en la fiesta sombría de los fondos, iluminando las carnes, las telas y los encajes. Aprovecha las poses teatrales de Van Dyck y los conocimientos de la técnica de Jordaens alimentada por la fuerza pictórica de Rubens. Realiza con ardor heroico sus murales históricos y a sus retratos supo dar cierta profundidad espiritual ungida de elegancia y de nobleza.

Vemos en este retrato del personaje desconocido que pertenece a la colección Pani, la gracia de la pose, y en la mano llena de luz está el gesto inactivo, más para mostrar la elegancia de la línea que para ejecutar cualquier acción.

Con la mise en scène de los fondos para sus retratos, y cierta simplicidad asociada a su pintura delicada, ausente de toda fantasía, nuestro pintor colecciona hechos históricos por mandato de sus superiores y dentro de la moda que gusta, obtiene el éxito que se merece, gracias a su fuerza técnica, a la construcción académica y forzada de sus composiciones, al equilibrio de sus tonos y a la elegancia de sus actitudes plásticas.

Su pintura sensual acusa una personalidad que, en apariencia frívola, inquieta al subrayar la psicología profunda y humana de su obra.

Muere lleno de honores y riquezas, en Friedrichstadt el 7 de diciembre de 1678.

\section{"Francisco Goitia", por Carlos Mérida ${ }^{33}$}

Si con atención vemos, dos, tres fechas de la vida de Francisco Goitia, percibiremos también en esa vida el irreductible carácter mexicano, En 1904, a los veinte años, Goitia está en Europa realizando el sueño soñado en su Zacatecas nativa: nuevos horizontes para revelar la fuerza que no sabía entonces cómo expresar.

Después de ocho años vividos en España y en Italia, Francisco Goitia vuelve a México, en 1912. Goitia se incorpora a la revolución cuyas filas no ha abandonado nunca.

Con la experiencia social que da la vida y la lucha, con lo mexicano más enraizado y más ágil a la vez, y con la enseñanza de Europa sirviéndole para

33. Carlos Mérida, "Francisco Goitia", Boletín Mensual Carta Blanca IV, núm. 3 (1937): s.p. 
fijar una expresión propia, Francisco Goitia que trabajó con el Dr. Gamio en el admirable experimento de San Juan Teotihuacán, pinta, durante esos años, sus mejores obras.

La amargura de Goitia, que a veces nos recuerda algo del espíritu de José Clemente Orozco, está impregnada, directamente, de su contacto con la vida del pueblo. Como Orozco, Francisco Goitia ha sido un hombre que ha sabido olvidarse de los demás para recordarse profundamente de sí mismo. Su pintura, sombría por la temática y luminosa por su fuerza lírica, posee también ese acento de veracidad, de autenticidad que le consagra como uno de los intérpretes plásticos de la revolución.

La obra y la vida de Francisco Goitia tienen la misma distinción, el mismo fraternal orgullo. Alejado por completo de la feria de vanidades que es la vida de los artistas pequeños en las ciudades grandes, Francisco Goitia, en su soledad preciosa, ha pintado obras como "Tata Jesucristo" — que reproducimos—, uno de los más acabados ejemplos de su talento.

\section{“C. Orozco Romero", por David Alfaro Siqueiros ${ }^{34}$}

La buena pintura, como todo arte, es síntesis de elementos contradictorios. De elementos opuestos que se excluyen entre sí y que, sin embargo, se engranan y coordinan. Es el ritmo de lo sincopado; es el maravilloso fruto que nace de un patético choque; es el tejido, la fusión musical de lo que es terso con lo que es áspero; es la recta que se estrella contra la curva y luego se quiebra en ángulos; y es, sobre todo, la estimulante y activa superposición de la física y la metafísica. Esto es: del mundo exterior y del mundo interior; de lo que se mira y palpa y de lo que, existiendo, "no existe" ni se mira. Mejor dicho: la coexistencia, la simultaneidad del oficio y del "misterio". Recuérdense las obras de todos los buenos pintores, y se encontrará invariablemente tal fenómeno: el Masaccio, por ejemplo. La pintura de Miguel Ángel, en cambio, era puramente física. Más espectacular y ampulosa, pero indudablemente de calidad inferior.

En la obra de Carlos Orozco Romero hay innegablemente, más que en muchos de los pintores consagrados de México, ese conflicto que es engranaje de valores encontrados y al cual me he referido antes. Siente la contradicción

34. David Alfaro Siqueiros, "C. Orozco Romero", Boletín Mensual Carta Blanca IV, núm. 8 (1937): s.p. 
armónica de las texturas opuestas; revuelve y agita igualmente lo terso con lo áspero; y mezcla lo agrio con la miel para que ésta sea más miel y lo agrio más agrio. Y en esto está en realidad su valor: lo objetivo con lo subjetivo, el nexo de la creación intocable con la materia del oficio.

Buena prueba de ese combate de contradicciones es la "Cabeza de Mujer", que ahora se publica. Dentro de lo limitado de la superficie, dentro de la precisión de la materia, trabajada con gran amor, se adivina el hondo drama plástico que la anima hasta hacer de ella un trozo de verdadera pintura realizado con el más auténtico aliento lírico.

\section{"Antonio Ruiz", por Carlos Mérida 35}

Comienza el público a fijarse - poderoso personaje indefinible — en la obra de Antonio Ruiz, pintor en plena madurez y producción, ya que sólo cuenta 40 años. Sus estudios en la Academia Nacional de Bellas Artes acaso no signifiquen nada importante en su vocación. Antonio Ruiz ha expuesto, en varias ocasiones, en los Estados Unidos y en Europa. En 1926 vivió en California y trabajó en el montaje de "sets" cinematográficos. Con estas experiencias se define en él uno de los aspectos más valiosos de su talento: la escenografía. Se ha especializado en la plástica de teatro para niños.

En una breve nota no es posible explicar con precisión su mexicanismo sin resabios folklóricos, lleno de encanto y de gracia. Su pintura se mantiene fiel a la tradición del retablo mexicano, por su pasión por el detalle, por lo acabado de su factura, por su dimensión manual que exige el dibujo exacto y un dominio grande del oficio. Pero sería la tradición culta, más bien que la verdaderamente popular, en donde hay un abandono infalsificable que Antonio Ruiz no busca nunca. Las pequeñas grandes obras de Ruiz están pintadas con la misma preciosidad de los mejores maestros de los siglos XVIII y XIX, anónimos en su mayor parte, que retrataron a nuestros abuelos.

El cuadro que hoy publica el Boletín Carta Blanca es un buen ejemplo de su labor. En él podemos sentir el mexicanismo del pintor, su talento original, y podemos admirar, a la vez, la habilidad y la gracia que le son peculiares. "Desfile" encierra, en efecto, su humor, su fina ironía, su pasión por

35. Carlos Mérida, “Antonio Ruiz”, Boletín Mensual Carta Blanca IV, núm. II (1938): s.p. 
el detalle, elementos ajustados cuidadosamente como los engranajes de una relojería primorosa.

Toda la obra de Antonio Ruiz se distingue por su dibujo incisivo y sin vacilaciones, por su composición llena de movimiento, por su observación costumbrista, elementos en los cuales obtiene siempre una creación verdadera.

\section{"Eugenio Landesio", por Carlos Mérida ${ }^{36}$}

Eugenio Landesio, el gran paisajista italiano, llegó a México en I855, llamado por Clavé, para impartir enseñanzas artísticas en la Academia Nacional de Bellas Artes, de la cual era director.

La obra de Landesio ya nos era conocida por haberse exhibido, con anterioridad a su llegada, buena parte de sus excelentes paisajes romanos, uno de los cuales se conserva en las Galerías del Palacio de las Bellas Artes.

Por espacio de diez y nueve años, el artista dio clases de perspectiva, - materia que conocía a la perfección-, de ornato y de paisaje. Su ejemplo creó una escuela en la que florecieron discípulos tan eminentes como José María Velasco, Luis Coto, José Jiménez y Javier Álvarez.

El arte de Eugenio Landesio sufrió un cambio radical al tener contacto con la luz del Valle de México. De las coloraciones calientes de sus cuadros romanos, pasa a la claridad tamizada y fría de la altiplanicie, característica que se hizo todavía más sutil y más insistente en la pintura de su auténtico sucesor: José María Velasco.

Landesio realizó obra copiosa en el país. Pintó cuadros de historia mexicana y una larga serie de paisajes, de los cuales, desgraciadamente, pocos se conservan en nuestra pinacoteca. Nos dejó un relato descriptivo de una excursión al Popocatépetl y a las Grutas de Cacahuamilpa, relato que ilustró con dibujos propios y con litografías de su discípulo Velasco.

Para Landesio, hijo espiritual de Claudio Lorena, el paisaje no constituía sino el digno marco de la figura. En toda su obra se observa tal peculiaridad. También es característico en la obra de Landesio el modo concreto de tratar sus motivos: todos los elementos que intervienen, inclusive las lejanías, tienen dibujo preciso.

36. Carlos Mérida, "Eugenio Landesio", Boletín Mensual Carta Blanca V, núm. 5 (1938): s.p. 
En la obra de José María Velasco, la figura ya no constituye parte orgánica del cuadro sino elemento afín al paisaje mismo. Nuestro gran viejo, al realizar sus maravillosas semblanzas plásticas del Valle de México, con esa personalísima concepción espacial que hizo su gloria y que dio tan acusada coloración a la escuela mexicana del paisaje, ya no se interesó en dar a los detalles carácter definido.

El cuadro "Chimalistac" — que aquí se reproduce- es una obra representativa del talento de Landesio en su manera mexicana. El tratamiento compacto de la materia, untuosa y fluida, el dibujo acusado y concreto, la coloración transparente y el grupo de figuras en los primeros términos, nos ofrece un ejemplo típico, no sólo de la época sino de la escuela. Landesio regresó a Europa en 1877, y murió en París dos años después. ‘ 
DOI: http://dx.doi.org/10.22201/iie.18703062e.2017.1.2594

240

ROBERTO ACEVES ÁVILA

\section{Anexo}

Cuadro I: Relación de artículos sobre arte publicados en el Boletín Mensual Carta Blanca*

\begin{tabular}{|c|c|c|c|c|}
\hline Ejemplar & Serie & Artículo & Autor & Ilustración \\
\hline $\begin{array}{l}\text { [Año I, número I, } \\
\text { marzo de I934]* }\end{array}$ & $\begin{array}{l}\text { Galería de Pintores } \\
\text { Modernos Mexicanos }\end{array}$ & Diego Rivera & Samuel Ramos & n.d. \\
\hline $\begin{array}{l}\text { [Año I, número 2, } \\
\text { abril de } 1934]^{*}\end{array}$ & $\begin{array}{l}\text { Galería de Pintores } \\
\text { Modernos Mexicanos }\end{array}$ & $\begin{array}{l}\text { Julio } \\
\text { Castellanos }\end{array}$ & $\begin{array}{l}\text { Luis Cardoza y } \\
\text { Aragón }\end{array}$ & n.d. \\
\hline $\begin{array}{l}\text { [Año I, número 2, } \\
\text { abril de I934]* }\end{array}$ & $\begin{array}{l}\text { Galería de Pintores } \\
\text { Modernos Mexicanos }\end{array}$ & $\begin{array}{l}\text { José Clemente } \\
\text { Orozco }\end{array}$ & Jorge Cuesta & n.d. \\
\hline $\begin{array}{l}\text { [Año I, número 4, } \\
\text { junio de } 1934]^{*}\end{array}$ & $\begin{array}{l}\text { Galería de Pintores } \\
\text { Modernos Mexicanos }\end{array}$ & Agustín Lazo & $\begin{array}{l}\text { Xavier } \\
\text { Villaurrutia }\end{array}$ & n.d. \\
\hline $\begin{array}{l}\text { [Año I, número 5, } \\
\text { julio de } 1934]^{*}\end{array}$ & $\begin{array}{l}\text { Galería de Pintores } \\
\text { Modernos Mexicanos }\end{array}$ & $\begin{array}{l}\text { Fermín } \\
\text { Revueltas }\end{array}$ & Carlos Mérida & n.d. \\
\hline $\begin{array}{l}\text { [Año I, número 6, } \\
\text { agosto de } 1934]^{*}\end{array}$ & $\begin{array}{l}\text { Galería de Pintores } \\
\text { Modernos Mexicanos }\end{array}$ & $\begin{array}{l}\text { David Alfaro } \\
\text { Siqueiros }\end{array}$ & José Gorostiza & n.d. \\
\hline $\begin{array}{l}\text { [Año I, número } \\
\text { 7, septiembre de } \\
\text { I934] }\end{array}$ & $\begin{array}{l}\text { Galería de Pintores } \\
\text { Modernos Mexicanos }\end{array}$ & $\begin{array}{l}\text { Jorge González } \\
\text { Camarena }\end{array}$ & $\begin{array}{l}\text { F. Sánchez } \\
\text { Fogarty }\end{array}$ & $\begin{array}{l}\text { "Núcleo". Óleo. Foto: } \\
\text { M. Álvarez Bravo. }\end{array}$ \\
\hline $\begin{array}{l}\text { [Año I, número } 8 \text {, } \\
\text { octubre de I934] }\end{array}$ & $\begin{array}{l}\text { Galería de Pintores } \\
\text { Modernos Mexicanos }\end{array}$ & Rufino Tamayo & $\begin{array}{l}\text { Celestino } \\
\text { Gorostiza }\end{array}$ & $\begin{array}{l}\text { "La Música". Fragmento } \\
\text { mural. Foto: M. Álvarez } \\
\text { Bravo. }\end{array}$ \\
\hline $\begin{array}{l}\text { [Año I, número 9, } \\
\text { noviembre de } \\
\text { I934] }\end{array}$ & $\begin{array}{l}\text { Galería de Pintores } \\
\text { Modernos Mexicanos }\end{array}$ & $\begin{array}{l}\text { Carlos Orozco } \\
\text { Romero }\end{array}$ & $\begin{array}{l}\text { Xavier } \\
\text { Villaurrutia }\end{array}$ & $\begin{array}{l}\text { "Paisaje". Foto: } \\
\text { M. Álvarez Bravo. }\end{array}$ \\
\hline $\begin{array}{l}\text { [Año I, } \\
\text { número Io, } \\
\text { diciembre de } \\
\text { I934] }\end{array}$ & $\begin{array}{l}\text { Galería de Pintores } \\
\text { Modernos Mexicanos }\end{array}$ & Carlos Mérida & Jorge Cuesta & $\begin{array}{l}\text { “Abstracción”. Acuarela. } \\
\text { Foto: M. Álvarez Bravo. }\end{array}$ \\
\hline $\begin{array}{l}\text { [Año II, número } \\
\text { I, abril de I935] }\end{array}$ & $\begin{array}{l}\text { El Arte en México. } \\
\text { Pintura Colonial. }\end{array}$ & $\begin{array}{l}\text { Alonso López } \\
\text { de Herrera }\end{array}$ & $\begin{array}{l}\text { Manuel } \\
\text { Romero de } \\
\text { Terreros }\end{array}$ & $\begin{array}{l}\text { “Transfixión de Santa } \\
\text { Teresa”. Von Stetten } \\
\text { Color Foto. Colección } \\
\text { del Lic. D. Francisco } \\
\text { Pérez Salazar. }\end{array}$ \\
\hline
\end{tabular}


DOI: http://dx.doi.org/10.22201/iie.18703062e.2017.1.2594

LOS ARTISTAS COMO CRÍTICOS

\begin{tabular}{|c|c|c|c|c|}
\hline Ejemplar & Serie & Artículo & Autor & Ilustración \\
\hline $\begin{array}{l}\text { Año II, número 2, } \\
\text { mayo de } 1935\end{array}$ & $\begin{array}{l}\text { El Arte en México. } \\
\text { Pintura Colonial. }\end{array}$ & $\begin{array}{l}\text { Juan Rodríguez } \\
\text { Juárez }\end{array}$ & $\begin{array}{l}\text { Luis Cardoza y } \\
\text { Aragón }\end{array}$ & $\begin{array}{l}\text { Fragmento de "La } \\
\text { Visitación". Von Stetten } \\
\text { Color Foto. Museo de } \\
\text { Guadalajara. }\end{array}$ \\
\hline $\begin{array}{l}\text { Año II, número 3, } \\
\text { junio de I } 935\end{array}$ & $\begin{array}{l}\text { El Arte en México. } \\
\text { Pintura Colonial. }\end{array}$ & $\begin{array}{l}\text { Baltazar de } \\
\text { Echave Orio, } \\
\text { llamado "El } \\
\text { Viejo" }\end{array}$ & $\begin{array}{l}\text { Manuel } \\
\text { Toussaint }\end{array}$ & $\begin{array}{l}\text { "San Francisco de } \\
\text { Asís". Von Stetten } \\
\text { Color Foto. Museo de } \\
\text { Guadalajara. }\end{array}$ \\
\hline $\begin{array}{l}\text { Año II, número 4, } \\
\text { julio de } 1935\end{array}$ & $\begin{array}{l}\text { El Arte en México. } \\
\text { Pintura colonial. }\end{array}$ & Pedro Ramírez & $\begin{array}{l}\text { Xavier } \\
\text { Villaurrutia }\end{array}$ & $\begin{array}{l}\text { Fragmento de "Cristo } \\
\text { atado a la columna". } \\
\text { Von Stetten Color Foto. } \\
\text { Museo de Guadalajara. }\end{array}$ \\
\hline $\begin{array}{l}\text { Año II, número } 5 \text {, } \\
\text { agosto de } 1935\end{array}$ & $\begin{array}{l}\text { El Arte en México. } \\
\text { Pintura Colonial. }\end{array}$ & José Ibarra & $\begin{array}{l}\text { Agustín Aragón } \\
\text { Leiva }\end{array}$ & $\begin{array}{l}\text { Fragmento de "Vida de } \\
\text { San Felipe Neri". Von } \\
\text { Stetten Color Foto. } \\
\text { Museo de Guadalajara. }\end{array}$ \\
\hline $\begin{array}{l}\text { Año II, número 6, } \\
\text { septiembre de } 1935\end{array}$ & $\begin{array}{l}\text { El Arte en México. } \\
\text { Pintura Colonial. }\end{array}$ & Juan Tinoco & $\begin{array}{l}\text { Antonio Castro } \\
\text { Leal }\end{array}$ & $\begin{array}{l}\text { "Apóstol Santiago". Von } \\
\text { Stetten Color Foto. } \\
\text { Museo de Puebla. }\end{array}$ \\
\hline $\begin{array}{l}\text { Año II, número } 7 \text {, } \\
\text { octubre de } 1935\end{array}$ & $\begin{array}{l}\text { El Arte en México. } \\
\text { Pintura Colonial. }\end{array}$ & Miguel Cabrera & $\begin{array}{l}\text { Enrique } \\
\text { Fernández } \\
\text { Ledesma }\end{array}$ & $\begin{array}{l}\text { Fragmento de "El Señor } \\
\text { de San José". Von Stetten } \\
\text { Color Foto. Museo de } \\
\text { Guadalajara. }\end{array}$ \\
\hline $\begin{array}{l}\text { Año II, número 8, } \\
\text { noviembre de } 1935\end{array}$ & $\begin{array}{l}\text { El Arte en México. } \\
\text { Pintura Colonial. }\end{array}$ & Echave el Mozo & $\begin{array}{l}\text { David Alfaro } \\
\text { Siqueiros }\end{array}$ & $\begin{array}{l}\text { Fragmento de "El triunfo } \\
\text { de la Iglesia". Von Stetten } \\
\text { Color Foto. Catedral de } \\
\text { Puebla. }\end{array}$ \\
\hline $\begin{array}{l}\text { Año II, número 9, } \\
\text { diciembre de } 1935\end{array}$ & $\begin{array}{l}\text { El Arte en México. } \\
\text { Pintura Colonial. }\end{array}$ & José Juárez & $\begin{array}{l}\text { Antonio } \\
\text { Acevedo } \\
\text { Escobedo }\end{array}$ & $\begin{array}{l}\text { "La Sagrada Familia”. } \\
\text { Von Stetten Color Foto. } \\
\text { Museo de Puebla. }\end{array}$ \\
\hline $\begin{array}{l}\text { Año III, número } \\
\text { Io, enero de I936 }\end{array}$ & $\begin{array}{l}\text { El Arte en México. } \\
\text { Pintura Colonial. }\end{array}$ & Luis Juárez & José Gorostiza & $\begin{array}{l}\text { "Santa Teresa". Von } \\
\text { Stetten Color Foto. } \\
\text { Museo de Guadalajara. }\end{array}$ \\
\hline $\begin{array}{l}\text { Año III, número } \\
\text { II, febrero de } 1936\end{array}$ & $\begin{array}{l}\text { El Arte en México. } \\
\text { Pintura Colonial. }\end{array}$ & $\begin{array}{l}\text { Miguel } \\
\text { Jerónimo } \\
\text { Zendejas }\end{array}$ & Jorge Cuesta & $\begin{array}{l}\text { "San Jerónimo". Von } \\
\text { Stetten Color Foto. } \\
\text { Museo de Puebla. }\end{array}$ \\
\hline
\end{tabular}


DOI: http://dx.doi.org/10.22201/iie.18703062e.2017.1.2594

242

ROBERTO ACEVES ÁVILA

\begin{tabular}{|c|c|c|c|c|}
\hline Ejemplar & Serie & Articulo & Autor & Ilustración \\
\hline $\begin{array}{l}\text { Año III, número } \\
\text { I, marzo de } 1936\end{array}$ & $\begin{array}{l}\text { Pintura Europea de } \\
\text { los Siglos XIV y Xv } \\
\text { en Colecciones de } \\
\text { México }\end{array}$ & $\begin{array}{l}\text { Peeter Jansz } \\
\text { Pourbus, El } \\
\text { Viejo }\end{array}$ & Carlos Mérida & $\begin{array}{l}\text { "Retrato de la Princesa } \\
\text { Isabel María". Color } \\
\text { Foto Cía. Litográfica "La } \\
\text { Enseńanza Objetiva- } \\
\text { México (L.E.o.s.A)". } \\
\text { Colección Pani. }\end{array}$ \\
\hline $\begin{array}{l}\text { Año III, número } \\
\text { II, abril de } 1936\end{array}$ & $\begin{array}{l}\text { Pintura Europea de } \\
\text { los Siglos XIV y xv } \\
\text { en Colecciones de } \\
\text { México }\end{array}$ & $\begin{array}{l}\text { Maestro de } \\
\text { la Magdalena } \\
\text { Manzi }\end{array}$ & José Gorostiza & $\begin{array}{l}\text { "Retrato". Color Foto } \\
\text { L.E.o.s.A. Colección Pani. }\end{array}$ \\
\hline $\begin{array}{l}\text { Año III, número } \\
\text { III, mayo de } 1936\end{array}$ & $\begin{array}{l}\text { Pintura Europea de } \\
\text { los Siglos XIV y Xv } \\
\text { en Colecciones de } \\
\text { México }\end{array}$ & $\begin{array}{l}\text { Jacques } \\
\text { Jordaens }\end{array}$ & $\begin{array}{l}\text { Luis Cardoza y } \\
\text { Aragón }\end{array}$ & $\begin{array}{l}\text { "Cabeza de Apóstol”. } \\
\text { Color Foto L.E.o.s.A. } \\
\text { Colección Pani. }\end{array}$ \\
\hline $\begin{array}{l}\text { Año III, número } \\
\text { IV, junio de } 1936\end{array}$ & $\begin{array}{l}\text { Pintura Europea de } \\
\text { los Siglos xIv y xv } \\
\text { en Colecciones de } \\
\text { México }\end{array}$ & Alvise Vivarini & $\begin{array}{l}\text { Carlos Orozco } \\
\text { Romero }\end{array}$ & $\begin{array}{l}\text { "Retrato". Color Foto } \\
\text { L.E.o.s.A. Colección Pani. }\end{array}$ \\
\hline $\begin{array}{l}\text { Año III, número } \\
\text { V, julio de } 1936\end{array}$ & $\begin{array}{l}\text { Pintura Europea de } \\
\text { los Siglos XIV y Xv } \\
\text { en Colecciones de } \\
\text { México }\end{array}$ & Franz Hals & $\begin{array}{l}\text { Antonin } \\
\text { Artaud }\end{array}$ & $\begin{array}{l}\text { "Retrato". Color Foto } \\
\text { L.E.o.s.A. Colección Pani. }\end{array}$ \\
\hline $\begin{array}{l}\text { Ańo III, número } \\
\text { VI, agosto de } 1936\end{array}$ & $\begin{array}{l}\text { Pintura Europea de } \\
\text { los Siglos XIV y Xv } \\
\text { en Colecciones de } \\
\text { México }\end{array}$ & $\begin{array}{l}\text { Antoon Van } \\
\text { Dyck }\end{array}$ & $\begin{array}{l}\text { Antonio Castro } \\
\text { Leal }\end{array}$ & $\begin{array}{l}\text { "La ninfa sorprendida } \\
\text { por un sátiro". Color } \\
\text { Foto L.E.o.s.A. Colección } \\
\text { Pani. }\end{array}$ \\
\hline $\begin{array}{l}\text { Año III, número } \\
\text { VII, septiembre } \\
\text { de } 1936\end{array}$ & $\begin{array}{l}\text { Pintura Europea de } \\
\text { los Siglos XIV y XV } \\
\text { en Colecciones de } \\
\text { México }\end{array}$ & Nicolaas Maes & Jorge Cuesta & $\begin{array}{l}\text { "Retrato". Color Foto } \\
\text { L.E.o.s.A. Colección Pani. }\end{array}$ \\
\hline $\begin{array}{l}\text { Año III, número } \\
\text { VIII, octubre de } \\
\text { I936 }\end{array}$ & $\begin{array}{l}\text { Pintura Europea de } \\
\text { los Siglos XIv y Xv } \\
\text { en Colecciones de } \\
\text { México }\end{array}$ & $\begin{array}{l}\text { Giovanni de } \\
\text { Nicolá }\end{array}$ & $\begin{array}{l}\text { Guillermo } \\
\text { Jiménez }\end{array}$ & $\begin{array}{l}\text { "Madonna". Color Foto } \\
\text { L.E.o.s.A. Colección Pani. }\end{array}$ \\
\hline
\end{tabular}


DOI: http://dx.doi.org/10.22201/iie.18703062e.2017.1.2594

LOS ARTISTAS COMO CRÍTICOS

\begin{tabular}{|c|c|c|c|c|}
\hline Ejemplar & Serie & Artículo & Autor & Ilustración \\
\hline $\begin{array}{l}\text { Año III, número } \\
\text { IX, noviembre de } \\
\text { I936 }\end{array}$ & $\begin{array}{l}\text { Pintura Europea de } \\
\text { los Siglos xiv y xv } \\
\text { en Colecciones de } \\
\text { México }\end{array}$ & Ovens Juriaane & $\begin{array}{l}\text { Roberto } \\
\text { Montenegro }\end{array}$ & $\begin{array}{l}\text { "Retrato". Color Foto } \\
\text { L.E.o.s.A. Colección Pani. }\end{array}$ \\
\hline $\begin{array}{l}\text { Año III, número } \\
\mathrm{X} \text {, diciembre de } \\
\text { I936 }\end{array}$ & $\begin{array}{l}\text { Pintura Europea de } \\
\text { los Siglos XIV y xv } \\
\text { en Colecciones de } \\
\text { México }\end{array}$ & $\begin{array}{l}\text { Roger Van Der } \\
\text { Weyden }\end{array}$ & $\begin{array}{l}\text { Bernardo Ortiz } \\
\text { de Montellano }\end{array}$ & $\begin{array}{l}\text { "Madona". Color Foto } \\
\text { L.E.o.s.A. Colección } \\
\text { Genaro Estrada. }\end{array}$ \\
\hline $\begin{array}{l}\text { Año III, número } \\
\text { XI, enero de } 1937\end{array}$ & $\begin{array}{l}\text { Pintura Europea de } \\
\text { los Siglos xiv y xv } \\
\text { en Colecciones de } \\
\text { México }\end{array}$ & $\begin{array}{l}\text { Bartolomé Van } \\
\text { Der Helst }\end{array}$ & $\begin{array}{l}\text { Xavier } \\
\text { Villaurrutia }\end{array}$ & $\begin{array}{l}\text { "Retrato". Color Foto } \\
\text { L.E.o.s.A. Colección Pani. }\end{array}$ \\
\hline $\begin{array}{l}\text { Año III, número } \\
\text { XII, febrero de } \\
\text { I937 }\end{array}$ & $\begin{array}{l}\text { Pintura Europea de } \\
\text { los Siglos XIV y XV } \\
\text { en Colecciones de } \\
\text { México }\end{array}$ & Guido Reni & Carlos Pellicer & $\begin{array}{l}\text { "Cabeza". Color Foto } \\
\text { L.E.o.s.A. Colección } \\
\text { Genaro Estrada. }\end{array}$ \\
\hline $\begin{array}{l}\text { Año IV, número I, } \\
\text { marzo de } 1937\end{array}$ & $\begin{array}{l}\text { El Arte en México. } \\
\text { Pintura Moderna } \\
\text { (Pintores Modernos } \\
\text { Mexicanos) }\end{array}$ & Diego Rivera & $\begin{array}{l}\text { Xavier } \\
\text { Villaurrutia }\end{array}$ & $\begin{array}{l}\text { "El Matemático". Color } \\
\text { Foto L.E.o.s.A. }\end{array}$ \\
\hline $\begin{array}{l}\text { Año IV, número } \\
\text { 2, abril de } 1937\end{array}$ & $\begin{array}{l}\text { El Arte en México. } \\
\text { Pintura Moderna } \\
\text { (Pintores Modernos } \\
\text { Mexicanos) }\end{array}$ & $\begin{array}{l}\text { J. Clemente } \\
\text { Orozco }\end{array}$ & Jorge Cuesta & $\begin{array}{l}\text { "Autorretrato". Color } \\
\text { Foto L.E.o.s.A., Galería } \\
\text { Central de Arte } \\
\text { Moderno. }\end{array}$ \\
\hline $\begin{array}{l}\text { Año IV, número } \\
\text { 3, mayo de I } 937\end{array}$ & $\begin{array}{l}\text { El Arte en México. } \\
\text { Pintura Moderna } \\
\text { (Pintores Modernos } \\
\text { Mexicanos) }\end{array}$ & $\begin{array}{l}\text { Francisco } \\
\text { Goitia }\end{array}$ & Carlos Mérida & $\begin{array}{l}\text { "Tata Jesucristo". Color } \\
\text { Foto L.E.o.s.A. Colección } \\
\text { Secretaría de Educación. }\end{array}$ \\
\hline $\begin{array}{l}\text { Año IV, número } \\
4 \text {, junio de I } 937\end{array}$ & $\begin{array}{l}\text { El Arte en México. } \\
\text { Pintura Moderna } \\
\text { (Pintores Modernos } \\
\text { Mexicanos) }\end{array}$ & $\begin{array}{l}\text { Roberto } \\
\text { Montenegro }\end{array}$ & Carlos Pellicer & $\begin{array}{l}\text { "Retrato". Color Foto } \\
\text { L.E.o.s.A. Colección del } \\
\text { autor. }\end{array}$ \\
\hline $\begin{array}{l}\text { Año IV, número } \\
\text { 5, julio de } 1937\end{array}$ & $\begin{array}{l}\text { El Arte en México. } \\
\text { Pintura Moderna } \\
\text { (Pintores Modernos } \\
\text { Mexicanos) }\end{array}$ & Carlos Mérida & $\begin{array}{l}\text { Octavio } \\
\text { Barreda }\end{array}$ & $\begin{array}{l}\text { "Ave de Paraíso". Color } \\
\text { Foto L.E.o.s.A. Colección } \\
\text { del autor. }\end{array}$ \\
\hline
\end{tabular}


DOI: http://dx.doi.org/10.22201/iie.18703062e.2017.1.2594

244 ROBERTO ACEVES Ávila

\begin{tabular}{|c|c|c|c|c|}
\hline Ejemplar & Serie & Artículo & Autor & Ilustración \\
\hline $\begin{array}{l}\text { Año IV, número } \\
\text { 6, agosto de I937 }\end{array}$ & $\begin{array}{l}\text { El Arte en México. } \\
\text { Pintura Moderna } \\
\text { (Pintores Modernos } \\
\text { Mexicanos) }\end{array}$ & $\begin{array}{l}\text { D. Alfaro } \\
\text { Siqueiros }\end{array}$ & Pedro Zuloaga & $\begin{array}{l}\text { "La Niña". Color Foto } \\
\text { L.E.o.s.A. (Retrato } \\
\text { de María Asúnsolo } \\
\text { nińa, actualmente en } \\
\text { el Mundial) }\end{array}$ \\
\hline $\begin{array}{l}\text { Año IV, número } \\
\text { 7, septiembre de } \\
\text { I937 }\end{array}$ & $\begin{array}{l}\text { El Arte en México. } \\
\text { Pintura Moderna } \\
\text { (Pintores Modernos } \\
\text { Mexicanos) }\end{array}$ & $\begin{array}{l}\text { M. Rodríguez } \\
\text { Lozano }\end{array}$ & $\begin{array}{l}\text { Jaime Torres } \\
\text { Bodet }\end{array}$ & $\begin{array}{l}\text { "Consuelo". Color Foto } \\
\text { L.E.O.s.A. }\end{array}$ \\
\hline $\begin{array}{l}\text { Año IV, número } \\
\text { 8, octubre de I } 937\end{array}$ & $\begin{array}{l}\text { El Arte en México. } \\
\text { Pintura Moderna } \\
\text { (Pintores Modernos } \\
\text { Mexicanos) }\end{array}$ & $\begin{array}{l}\text { C. Orozco } \\
\text { Romero }\end{array}$ & $\begin{array}{l}\text { David Alfaro } \\
\text { Siqueiros }\end{array}$ & $\begin{array}{l}\text { "Cabeza de Mujer". } \\
\text { Color Foto L.E.o.s.A. }\end{array}$ \\
\hline $\begin{array}{l}\text { Año IV, número } \\
\text { 9, noviembre de } \\
\text { I937 }\end{array}$ & $\begin{array}{l}\text { El Arte en México. } \\
\text { Pintura Moderna } \\
\text { (Pintores Modernos } \\
\text { Mexicanos) }\end{array}$ & Rufino Tamayo & $\begin{array}{l}\text { Octavio G. } \\
\text { Barreda }\end{array}$ & $\begin{array}{l}\text { "Retrato". Color Foto } \\
\text { L.E.o.s.A. Galería de Arte } \\
\text { Mexicano. }\end{array}$ \\
\hline $\begin{array}{l}\text { Año IV, número } \\
\text { Io, diciembre de } \\
\text { I937 }\end{array}$ & $\begin{array}{l}\text { El Arte en México. } \\
\text { Pintura Moderna } \\
\text { (Pintores Modernos } \\
\text { Mexicanos) }\end{array}$ & Agustín Lazo & $\begin{array}{l}\text { Xavier } \\
\text { Villaurrutia }\end{array}$ & $\begin{array}{l}\text { "Retrato". Color Foto } \\
\text { L.E.o.s.A. Galería de la } \\
\text { Universidad Nacional. }\end{array}$ \\
\hline $\begin{array}{l}\text { Año IV, número } \\
\text { II, enero de I938 }\end{array}$ & $\begin{array}{l}\text { El Arte en México. } \\
\text { Pintura Moderna } \\
\text { (Pintores Modernos } \\
\text { Mexicanos) }\end{array}$ & Antonio Ruiz & Carlos Mérida & $\begin{array}{l}\text { "Desfile". Color Foto } \\
\text { L.E.o.s.A. Galería de la } \\
\text { Universidad Nacional. }\end{array}$ \\
\hline $\begin{array}{l}\text { Año IV, número } \\
\text { I2, febrero de } 1938\end{array}$ & $\begin{array}{l}\text { El Arte en México. } \\
\text { Pintura Moderna } \\
\text { (Pintores Modernos } \\
\text { Mexicanos) }\end{array}$ & $\begin{array}{l}\text { G. Fernández } \\
\text { Ledesma }\end{array}$ & $\begin{array}{l}\text { Guillermo } \\
\text { Jiménez }\end{array}$ & $\begin{array}{l}\text { "Retrato". Color Foto } \\
\text { L.E.o.s.A. Galería de la } \\
\text { Universidad Nacional. }\end{array}$ \\
\hline $\begin{array}{l}\text { Año IV, número } \\
\text { I3, marzo de } \\
\text { I938* }\end{array}$ & $\begin{array}{l}\text { El Arte en México. } \\
\text { Pintura Moderna } \\
\text { (Pintores Modernos } \\
\text { Mexicanos) }\end{array}$ & n.d. & n.d. & n.d. \\
\hline
\end{tabular}


DOI: http://dx.doi.org/10.22201/iie.18703062e.2017.1.2594

LOS ARTISTAS COMO CRÍTICOS

\begin{tabular}{|c|c|c|c|c|}
\hline Ejemplar & Serie & Artículo & Autor & Ilustración \\
\hline $\begin{array}{l}\text { Año } \mathrm{V} \text {, número I, } \\
\text { abril de } 1938\end{array}$ & $\begin{array}{l}\text { La Pintura Mexicana } \\
\text { de fines del Siglo XIX } \\
\text { y principios del xx } \\
\text { (Pintura de los Siglos } \\
\text { XIX y Xx). }\end{array}$ & $\begin{array}{l}\text { José Luis } \\
\text { Rodríguez de } \\
\text { Alconedo }\end{array}$ & $\begin{array}{l}\text { Manuel } \\
\text { Toussaint }\end{array}$ & $\begin{array}{l}\text { "Autorretrato". Color } \\
\text { Foto L.E.o.s.A. Academia } \\
\text { de Bellas Artes-Puebla. }\end{array}$ \\
\hline $\begin{array}{l}\text { Año } \mathrm{V} \text {, número } 2 \text {, } \\
\text { mayo de } 1938\end{array}$ & $\begin{array}{l}\text { La Pintura Mexicana } \\
\text { de fines del Siglo XIX } \\
\text { y principios del xx } \\
\text { (Pintura de los Siglos } \\
\text { xIX y Xx). }\end{array}$ & Pelegrín Clavé & $\begin{array}{l}\text { Guillermo } \\
\text { Jiménez }\end{array}$ & $\begin{array}{l}\text { "Retrato de Dońa } \\
\text { Rosario Echavarría". } \\
\text { Color Foto L.E.o.s.A. } \\
\text { Galería del Palacio de } \\
\text { Bellas Artes. }\end{array}$ \\
\hline $\begin{array}{l}\text { Año } \mathrm{V} \text {, número } 3 \text {, } \\
\text { junio de } 1938\end{array}$ & $\begin{array}{l}\text { La Pintura Mexicana } \\
\text { de fines del Siglo XIX } \\
\text { y principios del xx } \\
\text { (Pintura de los Siglos } \\
\text { XIX y Xx). }\end{array}$ & $\begin{array}{l}\text { José María } \\
\text { Estrada }\end{array}$ & $\begin{array}{l}\text { Xavier } \\
\text { Villaurrutia }\end{array}$ & $\begin{array}{l}\text { “Retrato”. Color Foto } \\
\text { L.E.o.s.A. Colección Lic. } \\
\text { José G. Zuno. }\end{array}$ \\
\hline $\begin{array}{l}\text { Año } \mathrm{V} \text {, número } 4 \text {, } \\
\text { julio de } 1938\end{array}$ & $\begin{array}{l}\text { La Pintura Mexicana } \\
\text { de fines del Siglo XIX } \\
\text { y principios del xx } \\
\text { (Pintura de los Siglos } \\
\text { XIX y xx). }\end{array}$ & Santiago Rebull & Samuel Ramos & $\begin{array}{l}\text { "Retrato". Color Foto } \\
\text { L.E.o.s.A. Galerías del } \\
\text { Palacio de Bellas Artes. }\end{array}$ \\
\hline $\begin{array}{l}\text { Año V, número } \\
\text { 5, agosto y } \\
\text { septiembre de } \\
\text { I938 } \\
\text { A partir de } \\
\text { este número se } \\
\text { renombra como } \\
\text { Boletín de Arte } \\
\text { Carta Blanca. }\end{array}$ & $\begin{array}{l}\text { La Pintura Mexicana } \\
\text { de fines del Siglo xIx } \\
\text { y principios del xx } \\
\text { (Pintura de los Siglos } \\
\text { XIX y Xx). }\end{array}$ & $\begin{array}{l}\text { Eugenio } \\
\text { Landesio }\end{array}$ & Carlos Mérida & $\begin{array}{l}\text { "Chimalistac". Color } \\
\text { Foto L.E.o.s.A. Galerías } \\
\text { del Palacio de Bellas } \\
\text { Artes. }\end{array}$ \\
\hline $\begin{array}{l}\text { Año } \mathrm{V} \text {, número } \\
6 \text {, octubre y } \\
\text { noviembre de } 1938\end{array}$ & $\begin{array}{l}\text { La Pintura Mexicana } \\
\text { de fines del Siglo XIx } \\
\text { y principios del xx } \\
\text { (Pintura de los Siglos } \\
\text { XIX y Xx). }\end{array}$ & $\begin{array}{l}\text { José María } \\
\text { Velasco }\end{array}$ & $\begin{array}{l}\text { Xavier } \\
\text { Villaurrutia }\end{array}$ & $\begin{array}{l}\text { "Un paseo en I866". } \\
\text { Color Foto L.E.O.s.A. } \\
\text { Academia de Bellas } \\
\text { Artes-Puebla. }\end{array}$ \\
\hline
\end{tabular}


DOI: http://dx.doi.org/10.22201/iie.18703062e.2017.1.2594

246 ROBERTO ACEVES ÁVILA

\begin{tabular}{clccc}
\hline \multicolumn{1}{c}{ Ejemplar } & \multicolumn{1}{c}{ Serie } & Artículo & Autor & Ilustración \\
\hline $\begin{array}{l}\text { Año V, número 7, } \\
\text { diciembre y enero }\end{array}$ & $\begin{array}{l}\text { La Pintura Mexicana } \\
\text { de fines del Siglo XIx }\end{array}$ & n.d. & n.d. & n.d. \\
& $\begin{array}{l}\text { y principios del xx } \\
\text { (Pintura de los Siglos }\end{array}$ & & & \\
& xIx y xx). & & \\
\hline
\end{tabular}

* Referencias tomadas del catálogo público en línea de la Biblioteca Francisco Xavier Clavigero de la Universidad Iberoamericana, consultadas el 6 y el 2I de febrero de 20I6, http://biblioteca. uia.mx/F/E2KTKGLRSHFD2V3I6SYL27D3UQXXQRDQI2VANNIQA36FXEJ3DR-20768?func=full-setset\&set_number $=018930 \&$ set_entry=000I3 $8 \&$ format $=999$. Otras referencias provienen directamente de la colección Francisco Ramírez, "Caracalla". 